\title{
Mass deposition fluxes of Saharan mineral dust to the tropical northeast Atlantic Ocean: an intercomparison of methods
}

\author{
N. Niedermeier ${ }^{1}$, A. Held ${ }^{2}$, T. Müller ${ }^{1}$, B. Heinold ${ }^{1, *}$, K. Schepanski ${ }^{1, *}$, I. Tegen ${ }^{1}$, K. Kandler ${ }^{3}$, M. Ebert ${ }^{3}$, \\ S. Weinbruch ${ }^{3}$, K. Read ${ }^{4,5}$, J. Lee ${ }^{4,5}$, K. W. Fomba ${ }^{1}$, K. Müller ${ }^{1}$, H. Herrmann ${ }^{1}$, and A. Wiedensohler ${ }^{1}$ \\ ${ }^{1}$ Leibniz Institute for Tropospheric Research, Leipzig, Germany \\ ${ }^{2}$ Bayreuth Center of Ecology and Environmental Research, University of Bayreuth, Bayreuth, Germany \\ ${ }^{3}$ Institute for Applied Geosciences, Darmstadt University of Technology, Darmstadt, Germany \\ ${ }^{4}$ Department of Chemistry, University of York, York, UK \\ ${ }^{5}$ National Centre for Atmospheric Science, University of York, York, UK \\ * formerly at: School of Earth and Environment, University of Leeds, Leeds, UK
}

Correspondence to: N. Niedermeier (nicole.niedermeier@ tropos.de)

Received: 24 October 2012 - Published in Atmos. Chem. Phys. Discuss.: 19 December 2012

Revised: 11 January 2014 - Accepted: 13 January 2014 - Published: 4 March 2014

\begin{abstract}
Mass deposition fluxes of mineral dust to the tropical northeast Atlantic Ocean were determined within this study. In the framework of SOPRAN (Surface Ocean Processes in the Anthropocene), the interaction between the atmosphere and the ocean in terms of material exchange were investigated at the Cape Verde atmospheric observatory (CVAO) on the island Sao Vicente for January 2009. Five different methods were applied to estimate the deposition flux, using different meteorological and physical measurements, remote sensing, and regional dust transport simulations. The set of observations comprises micrometeorological measurements with an ultra-sonic anemometer and profile measurements using 2-D anemometers at two different heights, and microphysical measurements of the sizeresolved mass concentrations of mineral dust. In addition, the total mass concentration of mineral dust was derived from absorption photometer observations and passive sampling. The regional dust model COSMO-MUSCAT was used for simulations of dust emission and transport, including dry and wet deposition processes. This model was used as it describes the AOD's and mass concentrations realistic compared to the measurements and because it was run for the time period of the measurements. The four observation-based methods yield a monthly average deposition flux of mineral dust of $12-29 \mathrm{ng} \mathrm{m}^{-2} \mathrm{~s}^{-1}$. The simulation results come close to the upper range of the measurements with an average value of $47 \mathrm{ng} \mathrm{m}^{-2} \mathrm{~s}^{-1}$. It is shown that the mass deposition flux of
\end{abstract}

mineral dust obtained by the combination of micrometeorological (ultra-sonic anemometer) and microphysical measurements (particle mass size distribution of mineral dust) is difficult to compare to modeled mass deposition fluxes when the mineral dust is inhomogeneously distributed over the investigated area.

\section{Introduction}

A variety of open questions concerning the mechanisms of the different steps of the mineral dust cycle exist. That includes, for example, the question to which extent mineral dust impacts on the carbon and bio-geochemical cycle and consequently on the $\mathrm{CO}_{2}$ levels by delivering micronutrients to oceanic and terrestrial ecosystems (Falkowski , 1997). A related question is how mineral dust is processed in the atmosphere (Fung et al., 2000; Mahowald et al., 2005; Jickells et al., 2005). One essential part of the mineral dust cycle is the deposition to the ocean, which is largely dominated by Aeolian mineral dust originating from the great deserts and being transported over wide ranges (Carlson and Prospero, 1972; Prospero and Carlson, 1972; Karyampudi, 1988). Especially over the ocean regions, wet and dry deposition of mineral dust plays an important role for bio-activity, since mineral dust serves as a source of nutrients (e.g., iron) for oceanic microorganisms such as phytoplankton. The fraction 
of the direct bio-available soluble iron in soils is reported to be extremely variable with $0.01-80 \%$ (Mahowald et al., 2005) and depending on source mineralogy and atmospheric processing (Baker and Croot, 2010; Shi et al., 2011). In open ocean regions, the availability of iron is the limiting factor for phytoplankton growth and controls nitrogen fixation (Martin and Fitzwater, 1988; Falkowski , 1997; Falkowski et al., 1998; Boyd et al., 2000). Nitrogen fixation is an important process especially in low nitrate regions like the northern Atlantic Ocean, which converts the gaseous $\mathrm{N}_{2}$ to bio-available $\mathrm{N}$ (Karl et al., 2002), a major nutrient for phytoplankton growth. There is a positive correlation between the iron deposition to the ocean, cyanobacteria (diazotrophs), that fix the nitrogen and nitrogen fixation rates (Falkowski , 1997; Moore et al., 2009).

The Saharan desert is the largest natural source for airborne mineral dust worldwide. The source strength varies between 130 and $5000 \mathrm{Tg} \mathrm{yr}^{-1}$ (Goudie and Middleton, 2006; Swap et al., 1996; Cakmur et al., 2006). Saharan mineral dust plumes moving towards the northern tropical Atlantic are observed during the whole year (Moulin et al., 1997; Engelstaedter et al., 2006). In wintertime, the Saharan mineral dust layers spread over the northeast Atlantic in the lowest atmospheric layers below $2 \mathrm{~km}$ height (Kaufmann et al., 2005), where dry deposition is the most efficient removal process. In contrast, in the summer months Saharan mineral dust transport is controlled by the African easterly jet, and occurs between 3 and $6 \mathrm{~km}$ height when the mineral dust layer is lifted above the trade winds inversion (Chiapello et al., 1995; Schepanski et al., 2009a). During this time, dry deposition events over the ocean emerge due to sinking of mineral dust containing air masses.

Most of the published data on deposition fluxes of mineral dust over the ocean arise from global model outputs (Prospero et al., 1996; Ginoux et al., 2001; Zender et al., 2003; Luo et al., 2003). However, global mineral dust simulations utilize meteorological fields and soil data as model input that are only available with low spatial resolution and contain large uncertainties. In contrast to global models, regional models provide better input for mineral dust conditions under specific meteorological situations with a better vertical resolution of mineral dust layers (Schepanski et al., 2009a). Additional uncertainties originate directly from the emission parameterizations of mineral dust. These are associated with the calibration of the emission equation coefficients and reflect the difficulties in determining the binding strength of desert soil and modeling of soil crusting. Current model estimates of key quantities such as emission fluxes and mass concentrations of mineral dust can vary from a factor of 2 on global scale to at least 1 order of magnitude in regional model studies (Zender et al., 2003; Laurent et al., 2010; Huneeus et al., 2011).

From the experimental point of view, Goossens and Rajot (2008) compared different techniques (of passive sampling) to obtain dry deposition fluxes in Western Niger. In addition to passive sampling on flat plate collectors, which is often used for dry deposition measurements (Duce et al., 1991), theoretical approaches using micrometeorological parameters were investigated and the deposition flux was calculated. A comparison of the different methods showed good agreement among each other. All methods have their advantages and disadvantages. Some methods of passive sampling are easy to handle, other methods (sampling on glass filters) need only a small amount of mineral dust. However, most data of the passive sampling methods are sensitive to wind erosion and need to be corrected for the collection efficiency of the sampler. There is also a risk of out splash of mineral dust from the collector and some collectors are sensitive to perturbations (e.g., through humans and animals). Another important issue is to correct the sampled grains for particle shape. The investigated theoretical approaches by Goossens and Rajot showed an overestimation of the deposition flux when the correction was not done.

However, atmospheric observations of mass concentration of mineral dust at the open ocean are sparse and there exists an uncertainty of fluxes from the atmosphere to the ocean (Jickells et al., 2005) due to the episodic nature of atmospheric deposition into the ocean. More observations of deposition fluxes of mineral dust in the remote ocean are recommended (Mahowald et al., 2005).

The multi-disciplinary project SOPRAN (Surface Ocean Processes in the Anthropocene), funded by the German Ministry for Education and Research (Bundesministerium für Bildung und Forschung, BMBF) and part of the multinational research consortium SOLAS (Surface Ocean Lower Atmosphere Study), among others focuses on a better understanding of the connection between the input of mineral dust to the ocean and the subsequent biological activities. Within this framework, the present study was conducted at the Cape Verde Islands in January 2009, to measure aerosol deposition fluxes. During this month, dust is predominantly transported by the West African Harmattan (October to May) (McTainsh et al., 1997) off the continent towards the Cape Verdes. Only dry deposition was observed for the period of the measurements. Different methods to measure dry deposition have been explored: several physical measurements to calculate mass concentrations of mineral dust in combination with micrometeorological and profile methods to calculate the deposition velocity were used to calculate the mass deposition flux of mineral dust by multiplying both parameters. Furthermore, mass deposition fluxes obtained by scanning electron microscopy of passive sampled mineral dust and of a regional transport model are used for comparison. 


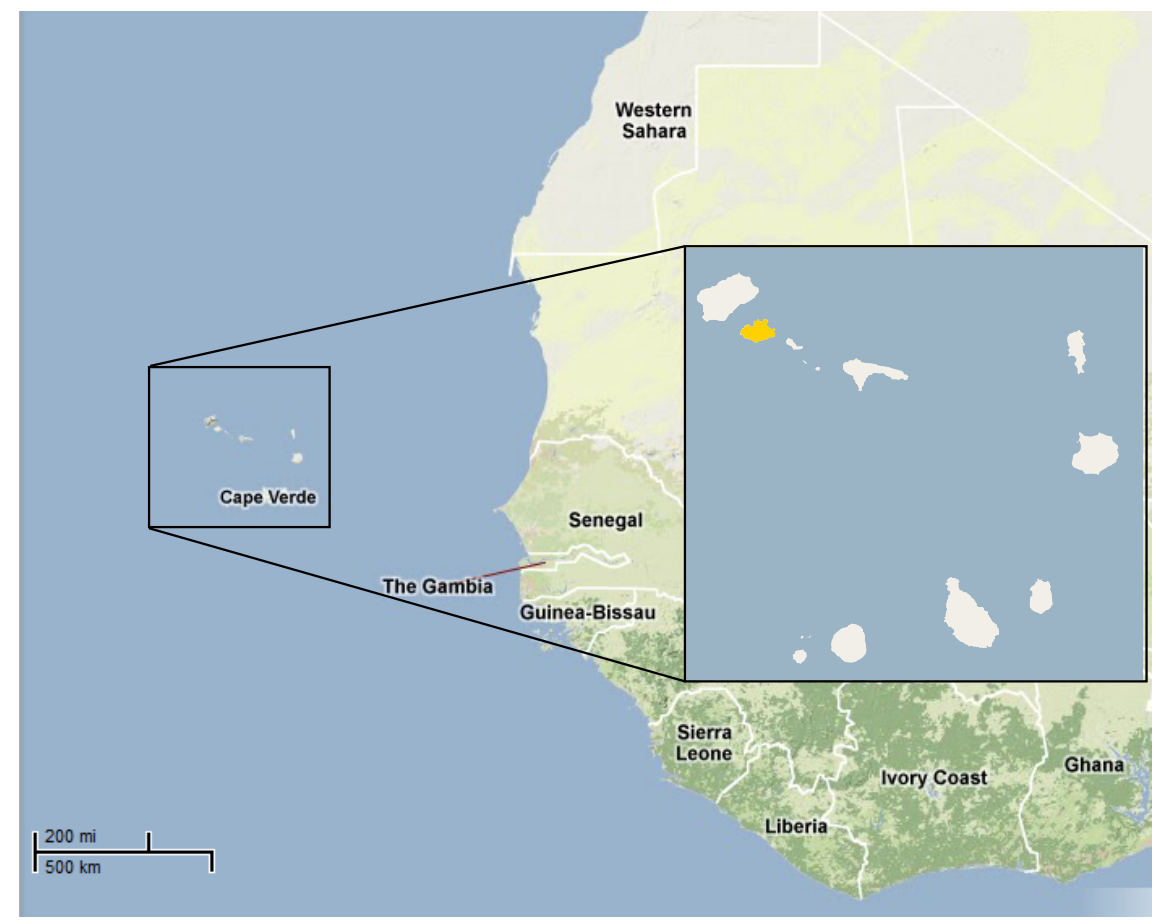

Fig. 1. Geographical position of the Cape Verde Islands (COpenStreetMap and contributors, CC-BY-SA). The orange island shows the position of Sao Vicente.

\section{Cape Verde atmospheric observatory}

\subsection{Location}

The field studies took place at the northeast side of the island Sao Vicente (Cape Verde) at $16^{\circ} 51^{\prime} \mathrm{N}, 24^{\circ} 52^{\prime} \mathrm{W}$ in the direct outflow of the Saharan desert (see Fig. 1). In 2006, the Cape Verde atmospheric observatory (CVAO) was installed to perform chemical and physical measurements of atmospheric gases and particles as well as bio-chemical investigations of the ocean surface (Carpenter et al., 2010). The site is located close to the shoreline, so that sea salt is mostly dominating the aerosol mass concentration. The CVAO is expected to be minimally influenced by anthropogenic emissions, as the wind is directly coming from the ocean and the African coast is approximately $900 \mathrm{~km}$ away. Furthermore, there is no other island upstream of the wind, which is predominantly coming from the northeast. A $30 \mathrm{~m}$ tower at the site provides space for installing instruments in different heights. Figure 2 shows the coastline of the island Sao Vicente with the CVAO marked as red square and a picture of the measuring tower including an overview of the position of the used instruments that are explained in more detail in the following.

\subsection{Instrumentation and data processing}

In Fig. 3, a scheme is shown including the instruments used to obtain the deposition velocity, mass concentration and mass deposition flux of mineral dust and the abbreviations used later in the text. Two devices were used to measure the deposition velocity and will later be referred to as micrometeorological $(\mathrm{mm})$ and profile method $(\mathrm{pm})$. Three devices including one or two instruments were used to obtain the mass concentration of mineral dust and the methods are using the different instruments are called microphysical (mp), optical (op) and gravimetrical (gr). Four combinations of the devices of the first two parameters were used to obtain the mass deposition flux of mineral dust. For the mass concentration and mass deposition flux of mineral dust, a model was also used which will be described later. The instruments used in this study are described in more detail hereinafter:

- Ultra-sonic and 2-D anemometers

- Mobility particle size spectrometer (SMPS) (as described in (Wiedensohler et al., 2012))

- Aerodynamic particle size spectrometer (APS) (TSI APS model 3321, TSI Inc., St. Paul Minnesota, USA)

- Hygroscopicity-Differential Mobility AnalyzerAerodynamic Particle Sizer (H-DMA-APS) (Leinert and Wiedensohler, 2008)

- Spectral optical absorption photometer (SOAP) (Müller et al., 2011)

- Sigma-2 passive sampler

- Berner 5-stage impactor 


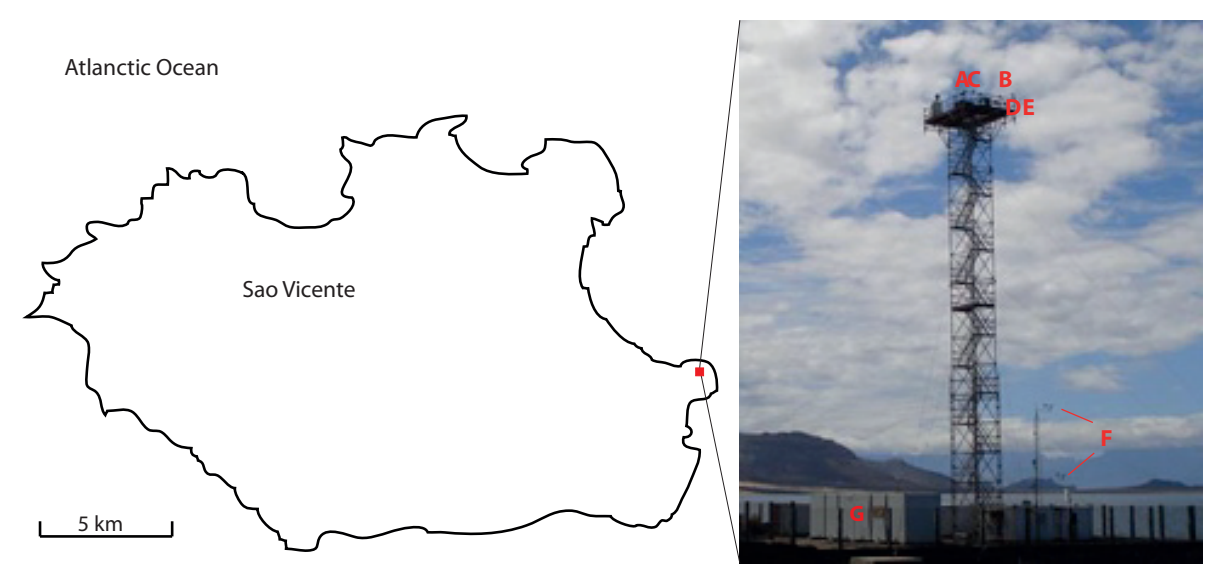

Fig. 2. Position of the Cape Verde atmospheric observatory on the island Sao Vicente and a picture of the measuring tower showing the position of the individual instruments.

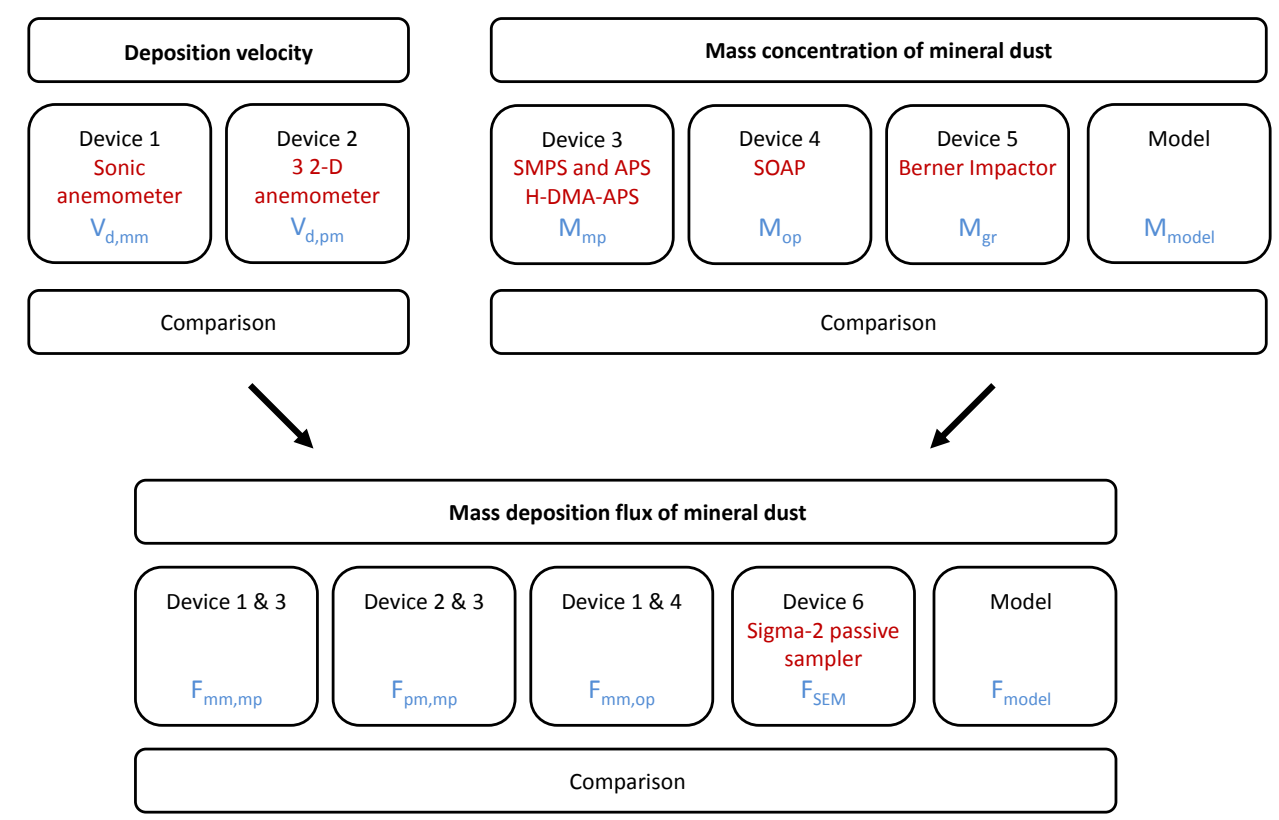

Fig. 3. Scheme of the measuring and evaluation procedure showing the instruments (red) and the used acronyms (blue) for the different methods of the three parameters of mineral dust: deposition velocity, mass concentration and mass deposition flux. The methods for the deposition velocity are called micrometeorological $(\mathrm{mm})$ and profile $(\mathrm{pm})$ and for the mass concentration of mineral dust microphysical (mp), optical (op), gravimetrical (gr) and in addition the output of a regional transport model (model) is used. The methods for the mass deposition flux of mineral dust are combinations of the previous methods and additionally from scanning electron microscopy of passive sampled particles (SEM) and from the regional transport model.

\subsubsection{Meteorological instrumentation}

For the January 2009 study, an ultra-sonic anemometer (Gill Instruments Limited, Lymington, Hampshire, UK) was installed $30 \mathrm{~m}$ above ground to obtain the 3-D wind velocity and direction. It was mounted on the northeast side on top of the tower and operated with a time resolution of $10 \mathrm{~Hz}$. A planar fit coordinate rotation was applied to turn the horizontal wind component in the streamline direction and afterwards covariances were calculated and averaged in 30 min periods.
Furthermore, 2-D wind velocity and wind direction at $10 \mathrm{~m}$ height were measured with a vane anemometer (model 05103, RM Young Wind Monitor). The instrument is installed on a smaller tower on top of a second container next to the tower. A third anemometer type (cup anemometer, BWS200, Campbell Scientific) is installed on top of the big tower at $30 \mathrm{~m}$ height. For all 2-D anemometers, the meteorological data are available with 1 minute time resolution. Temperature and relative humidity data from $8 \mathrm{~m}$ and $30 \mathrm{~m}$ were measured using a CS215 probe (Campbell Scientific). 


\subsubsection{Sampling system}

A $30 \mathrm{~m}$-long stainless steel sampling pipe with an outer diameter of $1 / 2$ inch connects a low flow $\mathrm{PM}_{10}$ inlet $\left(16.6 \mathrm{~L} \mathrm{~min}^{-1}\right)$ on top of the tower with an air-conditioned container housing the measurement equipment. Corrections for aerosol particle losses by diffusion, sedimentation and impaction in the entire sampling system were taken into account according to correction functions given in Baron and Willeke (2001). An automatic aerosol dryer as described in Tuch et al. (2009) is employed to avoid condensation in the sampling pipes and to dry the aerosol to a relative humidity lower than $40 \%$.

\subsubsection{Mobility particle size spectrometer (SMPS)}

The mobility particle size spectrometer operating in scanning mode (SMPS) determines the particle number size distribution in the diameter range between 10 and $880 \mathrm{~nm}$. It appears to be incomplete.. The setup of this mobility particle size spectrometer is described in detail in Wiedensohler et al. (2012). Inside, the aerosol is additionally dried by a Nafion membrane to a relative humidity (RH) lower than $35 \%$ and charged in a bipolar diffusion charger to obtain a bipolar charge distribution (Wiedensohler, 1988). Afterwards, particles with a certain electrical mobility are selected in a DMA (differential mobility analyzer, type Hauke medium) (Knutson and Whitby, 1975), which was operated with an aerosol flow of $0.5 \mathrm{~L} \mathrm{~min}^{-1}$ and a sheath air flow of $5 \mathrm{~L} \mathrm{~min}^{-1}$. The DMA voltage is permanently increased (up scan) until the top voltage of $10.5 \mathrm{kV}$ (which corresponds to a particle size of $880 \mathrm{~nm}$ ) and afterwards decreased (down scan) to zero again. The number concentration of particles for each mobility class is measured by a CPC (condensation particle counter, TSI 3010, TSI Inc., St. Paul Minnesota, USA). Both up and down scans are merged to one mobility size distribution, which is finally converted to a particle number size distribution by a multiple charge correction inversion routine. According to Wiedensohler et al. (2012), the error in sizing is approximately $11 \%$ concerning sheath air flow deviation, relative humidity and pressure variation.

\subsubsection{Aerodynamic particle size spectrometer (APS)}

The aerodynamic particle number size distribution is obtained by an aerodynamic particle size spectrometer (TSI APS model 3321, TSI Inc., St. Paul Minnesota, USA) in the range between 0.6 and $10 \mu \mathrm{m}$. The inlet flow of $5 \mathrm{~L} \mathrm{~min}^{-1}$ is divided into a $1 \mathrm{~L} \mathrm{~min}^{-1}$ aerosol and a $4 \mathrm{~L} \mathrm{~min}^{-1}$ sheath air flow. Particles are focused by an inner nozzle and accelerated by the sheath air in an outer nozzle. By passing two laser beams, the time of flight of one particle is obtained and converted to the aerodynamic diameter of the particle. There is a measurement uncertainty of the APS due to the counting principle of the system, which yields a maximum uncertainty in sizing of $15 \%$ for these measurements.

\subsubsection{Combining mobility and aerodynamic size distributions}

Both the mobility and aerodynamic particle size spectrometers measure particle number size distributions in different size ranges that can be combined. The measurement techniques use different particle properties yielding in mobility and aerodynamic particle diameters. To combine the mobility and the aerodynamic particle number size distribution, the mobility and aerodynamic diameters have to be converted to volume equivalent diameters. By knowing the particle density and the shape factor (mineral dust or pure sea salt), either from literature or from measurements, the volume equivalent diameters can be calculated following Eqs. 1 and 2 (DeCarlo et al., 2004):

$$
\begin{aligned}
& D p_{\mathrm{ve}}=D p_{\text {aero }} \cdot \sqrt{\frac{\chi \cdot \rho_{0}}{\rho} \cdot \frac{C_{\mathrm{c}, \text { aero }}}{C_{\mathrm{c}, \mathrm{ve}}}}, \\
& D p_{\mathrm{ve}}=\frac{D p_{\mathrm{Zp}}}{\chi} \cdot \frac{C_{\mathrm{c}, \mathrm{ve}}}{C_{\mathrm{c}, \mathrm{Zp}}}
\end{aligned}
$$

with $D p_{\text {ve }}, D p_{\text {aero }}$ and $D p_{\text {Zp }}$ being the volume equivalent, the aerodynamic and the mobility diameter, respectively. $\chi$ is the aerodynamic shape factor, $\rho$ is the particle density and $\rho_{0}$ is the standard density $\left(1 \mathrm{~g} \mathrm{~cm}^{-3}\right)$. The Cunningham slip correction factors $C_{\mathrm{c}, \mathrm{ve}}, C_{\mathrm{c} \text {,aero }}$ and $C_{\mathrm{c}, \mathrm{Zp}}$ to correct for the reduction in drag, when the relative velocity at the particle's surface is nonzero (Hinds, 1999), are also included.

After this conversion, the volume equivalent diameters of both instruments were put into a new grid with a logarithmic equidistant distance of 0.03 . The corresponding number concentrations were calculated by a linear interpolation. The largest measured mobility diameter is equal to a volume equivalent diameter of $733 \mathrm{~nm}$ and the smallest used aerodynamic diameter of $723 \mathrm{~nm}$ corresponds to a volume equivalent diameter of about $538 \mathrm{~nm}$, depending on the use of $\chi$ and $\rho$ (here 1.17 and $2.45 \mu \mathrm{g} \mathrm{cm}^{-3}$, respectively). Therefore, a couple of overlapping diameters from 538 to $733 \mathrm{~nm}$ of both distributions exist. Before both distributions were merged by averaging the number concentration of the overlapping diameters, the mobility particle number size distribution was inverted and multiple charge corrections by considering the aerodynamic particle number size distribution were performed. The resulting particle number size distribution ranges from 0.01 to $10 \mu \mathrm{m}$.

\subsubsection{Hygroscopicity-Differential Mobility Analyzer- Aerodynamic Particle Sizer (H-DMA-APS)}

The H-DMA-APS is designed to distinguish particles according to their hygroscopic behavior. Measured parameters are the hygroscopic growth factor and the number fraction 
of hydrophobic and hygroscopic particles. The measuring principle is the following: first, particles are selected according to their electrical mobility. Here, a specially designed DMA (length $=75 \mathrm{~cm}$; inner diameter $=72 \mathrm{~mm}$; outer diameter $=80 \mathrm{~mm}$ ) with an aerosol flow rate of 1 or $2 \mathrm{~L} \mathrm{~min}^{-1}$ and a sheath air flow rate of 10 or $20 \mathrm{~L} \mathrm{~min}^{-1}$ is used to select particles with mobility diameters of 600,800 and $1000 \mathrm{~nm}$. It is essential that particles are dried below $30 \% \mathrm{RH}$ before they enter the DMA to ensure that they are below the efflorescence point of the most soluble materials such as sodium chloride. Afterwards, the aerosol is either humidified to approximately $90 \% \mathrm{RH}$ or kept at dry state $(\mathrm{RH}<30 \%)$. Finally, the aerodynamic particle number size distribution of the dry or humidified particles are measured with an APS.

Calibration scans with ammonium sulfate were performed regularly to recalculate the $\mathrm{RH}$, to which the aerosol particles were exposed to. Furthermore, polystyrene latex (PSL) scans were taken to check the sizing accuracy of the APS. By measuring the humidified particle number size distribution with the H-DMA-APS, two distinct modes were observed. The first mode is attributed to less growing mineral dust particles, the second one to more growing sea salt particles. A lognormal fit procedure was performed on both modes to obtain the particle number concentration in the respective mode. By dividing the number of mineral dust particles through the number of total particles (mineral dust and sea salt), the number fraction of mineral dust was obtained.

\subsubsection{Spectral optical absorption photometer (SOAP)}

Spectral particle absorption coefficients were measured by a spectral optical absorption photometer (SOAP) (Müller et al., 2011). The SOAP covers the wavelength range from 300 to $950 \mathrm{~nm}$ with a resolution of $50 \mathrm{~nm}$. The detection limit is $0.25 \mathrm{Mm}^{-1}$ for wavelengths larger than $450 \mathrm{~nm}$ and $0.5 \mathrm{Mm}^{-1}$ for smaller wavelengths. The instrumental errors are about $15 \%$ for measuring the absorption coefficient. An additional error because of a cross sensitivity to particle scattering cannot be determined since the scattering coefficient was not measured. For similar conditions during the SAMUM-2 campaign in January 2008 based at Praia, Cape Verde (Müller et al., 2011) with scattering coefficients being 20 times higher than absorption coefficients, a total error of about $55 \%$ can be estimated. From the spectral absorption coefficients, the mineral dust concentration can be estimated as described in paragraph 3.2.2.

\subsubsection{Sigma-2 passive sampler and scanning electron microscopy (SEM)}

Dry deposition was measured with sedimentation traps. A Sigma-2 passive sampler (VDI, 2007) was installed at the tower at $30 \mathrm{~m}$ height. The sampler was fixed at the northwest side, sufficiently far away from the tower framework to minimize sampling artifacts. For collecting particles, a glassy carbon substrate was chosen due to its extraordinary smooth surface allowing for a clear image-analytical separation of particles and background (Ebert et al., 1997). However, as the substrate is not sticky, a fraction of the particles might be re-entrained into the atmosphere during heavy gusts, though the Sigma-2 sampler minimizes the interior flow velocity. As a result, the mass deposition rates might be underestimated by this method and serve as a minimum estimate.

The exposition time was 1 week for a period of 4 weeks in total. Sample handling was performed in a dry, clean place inside the measuring container undisturbed from the air conditioner and the instruments. The particles on the glassy carbon substrates were analyzed by scanning electron microscopy with coupled energy-dispersive X-ray microanalysis (Kandler et al., 2009). As the analyses are performed under vacuum conditions, the determined quantity is dry deposited particle mass. For each particle, a secondary electron image and the elemental composition was recorded. From the particle cross section, the particle diameter was inferred (projected area diameter). Assuming a flat orientation on the substrate, the height of the particles was set as the shorter axis of the 2-D ellipse fitting the particle outline. From the area covered by the particle and the height, the volume was estimated. The elemental composition information was used to assign each particle an according material density, which was used to calculate its mass.

\subsubsection{Berner 5-stage impactor (Berner)}

A 5-stage Berner low-pressure impactor was used downstream of a $\mathrm{PM}_{10}$ inlet for collecting samples for sizeresolved analysis (Müller et al., 2010). The impactor made of stainless steel was mounted on top of the $30 \mathrm{~m}$ tower and was operated with a flow rate of $75 \mathrm{~L} \mathrm{~min}^{-1}$. Pre-heated $(2 \mathrm{~h}$ at $350^{\circ} \mathrm{C}$ ) aluminum foils and Nuclepore polycarbonate foils were used as substrate. The polycarbonate foils were placed on the aluminum foils on each impactor stage and were used for the determination of trace metals. The impactor stages have the following aerodynamic size cutoffs: stage $1-0.05-$ $0.14 \mu \mathrm{m}$, stage $2-0.14-0.42 \mu \mathrm{m}$, stage $3-0.42-1.2 \mu \mathrm{m}$, stage $4-1.2-3.5 \mu \mathrm{m}$, stage $5-3.5-10 \mu \mathrm{m}$.

\section{Calculation of the mass deposition flux of mineral dust}

This section describes the different methods to measure mass concentrations of mineral dust and deposition velocities and introduces the model used in this study for comparison.

Particle deposition fluxes $F$ are calculated by multiplying the mass concentration $M_{\text {conc }}$ and the deposition velocity $v_{\mathrm{d}}$ :

$F=-v_{\mathrm{d}} \cdot M_{\text {conc }}$.

The negative sign in this equation indicates a downward directed deposition flux. 
The mass deposition flux of mineral dust published in the last years mostly belongs to measurements using sampling methods (e.g., Arimoto et al., 1997) and from global model outputs (Prospero et al., 1996; Ginoux et al., 2001; Zender et al., 2003; Luo et al., 2003). In order to have a large pool of values for the mass deposition flux of mineral dust to compare against each other, different methods using the previous described instruments will be introduced in the following. Using the different methods shows the accuracy of each resulting in a range of values for the mass deposition flux of mineral dust and thus increasing the level of confidence of this value. Additionally, methods showing a too large deviation can be determined. As the mass deposition flux of mineral dust can be obtained by using Eq. (3), also different methods for calculating the deposition velocity and the mass concentration of mineral dust need to be investigated. Figure 3 gives an overview of the acronyms of the different methods explained in more detail in the following and the used instruments to obtain the different parameters.

\subsection{Deposition velocities}

The methods to calculate (size resolved) dry deposition velocities described hereafter are based on the parameterization by Zhang et al. (2001), which accounts for turbulent transfer, Brownian diffusion, impaction, interception, gravitational settling, and particle rebound (Zhang et al., 2001; Held et al., 2006). The dry deposition velocity $\left(v_{d}\right)$ is based on the resistance approach of Slinn and Slinn (1980) as implemented by Kumar (1996):

$v_{d}=\frac{1}{R_{\mathrm{a}}+R_{\mathrm{s}}+R_{\mathrm{a}} R_{\mathrm{s}} v_{\mathrm{g}}}+v_{\mathrm{g}}$,

where $R_{\mathrm{a}}$ and $R_{\mathrm{S}}$ denote the aerodynamic and surface resistance, respectively, based on Zhang et al. (2001). $v_{\mathrm{g}}$ is the gravitational settling velocity with

$v_{\mathrm{g}}=\frac{\left(\rho_{\mathrm{p}}-\rho_{\mathrm{a}}\right) \cdot g \cdot D p^{2} \cdot C_{c}}{18 \mu}$.

$\rho_{\mathrm{p}}$ and $\rho_{\mathrm{a}}$ are the density of the particle and the air, respectively, $g$ is the gravitational constant and $\mu$ is the dynamic viscosity of air.

To validate the output of the model, Zhang et al. (2001) compared the calculated dry deposition velocity to results from two empirical models - the sulfate dry deposition model from Wesely et al. (1985) and a deposition model by Ruijgrok et al. (1997). Different land use categories were applied for the model in Zhang et al. (2001), for example, grass, desert, ocean, and urban. The best agreement with the other two models was found for the land category "ocean" (Zhang et al., 2001), which is the one used for this study since the measurements were performed at an ocean site.

\subsubsection{Micrometeorological method $\left(v_{\mathrm{d}, \mathrm{mm}}\right)$}

Parameters measured by the ultra-sonic anemometer were the sonic temperature $T_{\mathrm{s}}$, the mean horizontal wind speed $U$ and the vertical wind speed $w$. Data with $2 \mathrm{~Hz}$ time resolution were averaged over $30 \mathrm{~min}$. Standard eddy-covariance procedures were used to calculate turbulent fluxes. The covariance of $T_{\mathrm{S}}$ and $w$ yields the buoyancy flux, which is related to the sensible heat flux $H$. As the sensible heat flux cannot be determined directly due to a lack of a direct fast response measurement of temperature $T$, the buoyancy flux using the sonic temperature $T_{\mathrm{S}}$ instead of the virtual temperature $T_{\mathrm{v}}$ (Foken, 2008) is calculated. The covariance of $U$ and $w$ yields the momentum flux $M$, from which the friction velocity $u_{*}$ is calculated by

$u_{*}=\sqrt{-M}$.

The roughness length $z_{0}$ can be obtained from the logarithmic wind profile for neutral atmospheric stability:

$z_{0}=z \cdot \exp \left[-\kappa \cdot \frac{u(z)}{u_{*}}\right]$,

with the van Karman constant $\kappa$ having a value of 0.4 , and the wind velocity $u(z)$ measured in height $z$.

The Obukhov length $L$ is defined by

$L=-\frac{T \cdot u_{*}^{3}}{\kappa \cdot g \cdot H}$,

which is a scaling factor of the atmospheric stability.

The calculated turbulence parameters were used in the deposition model after Zhang et al. (2001) to compute sizeresolved dry deposition velocities for the particle diameters of the particle mass size distribution of mineral dust, and a specific value of the deposition velocity for the particle diameter, where $90 \%$ of the mass of the particle mass size distribution of mineral dust was reached $(2.25 \mu \mathrm{m})$.

\subsubsection{Profile method $\left(v_{\mathrm{d}, \mathrm{pm}}\right)$}

For this method, the horizontal wind velocity at 10 and $30 \mathrm{~m}$ height is used. To derive the turbulent parameters $u_{*}$ and $z_{0}$, again, the validity of the logarithmic wind profile (Eq. 7) is assumed:

$$
\underbrace{u(z)}_{y_{i}}=\frac{u_{*}}{\kappa} \cdot \ln \left(\frac{z}{z_{0}}\right)=\underbrace{\frac{u_{*}}{\kappa} \cdot \ln (z)}_{b \cdot x_{i}}-\underbrace{\frac{u_{*}}{\kappa} \cdot \ln \left(z_{0}\right)}_{\mathrm{a}} .
$$

The application of a linear regression to this equation and using the residuum of the sum of squares yields an equation for term $b$ (Taubenheim, 1969):

$b=\frac{\sum_{i}\left(z_{i}-\bar{z}\right) \cdot\left(u_{i}-\bar{u}\right)}{\sum_{i}\left(z_{i}-\bar{z}\right)^{2}}$, 
with the numerator being the covariance of the parameters $z$ and $u\left(S_{z u}\right)$ and the denominator being the variance of the parameter $z\left(S_{z z}\right)$. With this approach, $u_{*}$ can be calculated as follows:

$b=\frac{S_{z u}}{S_{z z}}=\frac{u_{*}}{\kappa} \rightarrow u_{*}=\kappa \cdot \frac{S_{z u}}{S_{z z}}$.

With the information of wind velocities at only two heights, Eq. (11) simplifies to Eq. (12):

$u_{*}=\kappa \cdot \frac{u\left(z_{2}\right)-u\left(z_{1}\right)}{\ln \left(z_{2}\right)-\ln \left(z_{1}\right)}$.

The sensible heat flux $H$ can also be calculated following Berkowicz and Prahm (1982) using the temperature measurements that are available at 8 and $30 \mathrm{~m}$ height above ground level:

$H=-\rho \cdot c_{\mathrm{p}} \cdot u_{*} \cdot \kappa \cdot \frac{\Delta T}{\Delta z}$,

where $\Delta T / \Delta z=\theta_{*}$ is a simplification for the characteristic temperature-scale parameter $\theta_{*}$.

Again, $z_{o}$ and $L$ were calculated according to the Eqs. 7 and 8 , respectively, and used together with the diameters of the particle mass size distribution of mineral dust in the deposition model after Zhang et al. (2001) to obtain size-resolved deposition velocities.

As will be seen in Sect. 4.1, the error of the micrometeorological method and the profile method is $22 \%$.

\subsubsection{Internal boundary layer}

This work deals with the dust mass that enters the ocean. However, the measurements were performed on an island. The following section will prove that dust mass deposition fluxes were calculated for conditions equivalent to that over the ocean.

The internal boundary layer (IBL) is defined as a layer that forms within an existing boundary layer when the air passes a surface with changing roughness lengths (Stull, 1988). For the presented measurements, the air comes from the ocean, exceeds the border (shoreline) to the island and an IBL can form. The height $\delta$ of the IBL at the measurement point (in this case the tower) depends on the distance of the tower to the border $(x)$, which is called fetch, and on the atmospheric layering. The fetch to the tower depends also on the wind direction. With the following equation from Stull (1988), $\delta$ can be estimated:

$\delta=z_{01} \cdot \alpha \cdot\left(\frac{x}{z_{01}}\right)^{\beta}$

with $\alpha$ and $\beta$ being parameters depending on the atmospheric layering and $z_{01}$ being the roughness length upwind of the border. To characterize the atmospheric layering, the measurement height $z$ is divided by the Obukhov length $L(z / L)$.
Table 1. Values for the stability parameter $z / L$ and the parameters $\alpha$ and $\beta$ that were taken to calculate the internal bounary layer height according to the atmospheric layering.

\begin{tabular}{cccc}
\hline Atm. layering & $\mathrm{z} / \mathrm{L}$ & $\alpha$ & $\beta$ \\
\hline Stable & $>0.1$ & $0.2-0.45$ & $0.6-0.75$ \\
Neutral & $-0.3-0.1$ & 0.5 & 0.8 \\
Unstable & $<-0.3$ & $0.55-0.8$ & $0.85-1.0$ \\
\hline
\end{tabular}

Table 1 summarizes the different types of atmospheric layering and values for the parameters $z / L, \alpha$ and $\beta$. Figure 5 shows a time series of the IBL height for neutral and unstable conditions. No stable conditions were found at the CVAO for January 2009; $66 \%$ of the investigated cases were neutral. As can be seen from Fig. 5, the IBL height for neutral atmospheric layering is mainly beneath $30 \mathrm{~m}$, which means that the ultra-sonic measurements represent the conditions over the ocean. Most of the unstable cases also show IBL heights beneath $30 \mathrm{~m}$. This shows that the assumption of the land use class "ocean" in the Zhang model is correct for most cases presented in this study. For calculating the fluxes with the micrometeorological method, just cases with IBL heights lower than $30 \mathrm{~m}$ were used. The same holds true for the 10 and $30 \mathrm{~m}$ wind measurements that were taken for the profile method when the IBL height was below $8 \mathrm{~m}$, since temperature measurements were performed in a height of $8 \mathrm{~m}$.

\subsection{Calculation of mass concentration of mineral dust}

\subsubsection{Mass concentration using the microphysical $\operatorname{method}\left(M_{\mathrm{mp}}\right)$}

Particle mass size distributions of mineral dust (PMSDmd) were derived from the total particle number size distribution and the number fraction of mineral dust. The H-DMA-APS provides number fractions of sea salt and mineral dust at the mobility diameters of 600,800 and $1000 \mathrm{~nm}$. The number fraction of mineral dust for the different particle diameters were multiplied with the concentration of the particle number size distribution for the respective diameter and a particle number size distribution of mineral dust was obtained. There is no information about the number fraction of mineral dust of particles larger than $1000 \mathrm{~nm}$ because the H-DMA-APS was only used up to this diameter. For larger particle diameters, the number concentration is too low leading to insufficient statistics. Therefore the number fraction of mineral dust particles of $1000 \mathrm{~nm}$ size was used also for particles larger than $1000 \mathrm{~nm}$. Afterwards, a log-normal distribution was fitted to the particle number size distribution of mineral dust (see Fig. 4) and converted into a particle mass size distribution by calculating the mass concentration $M_{i}$ of each size channel using the following equation:

$M_{i}=N_{i} \cdot \frac{\pi}{6} \cdot D p_{i}^{3} \cdot \rho_{\mathrm{md}}$, 


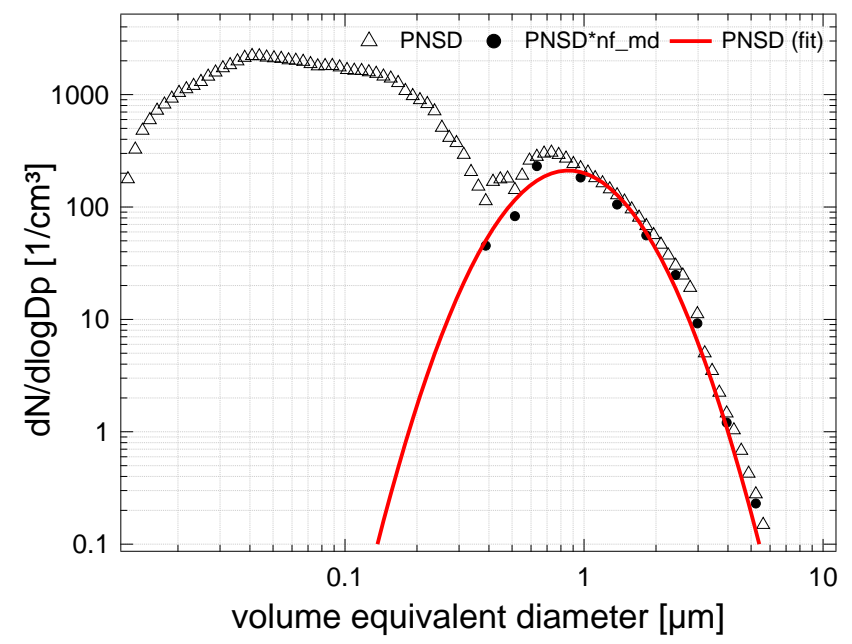

Fig. 4. Fractional particle number size distribution of mineral dust (black sphere) resulting from the multiplication of the total particle number size distribution (open triangles) and the number fraction of mineral dust with the assumption that the number fraction of mineral dust for particles larger than $1000 \mathrm{~nm}$ has the same value as the number fraction of mineral dust for $1000 \mathrm{~nm}$. Additionally, a log-normal fit (red line) through the black spheres is shown which yields the particle number size distribution of mineral dust.

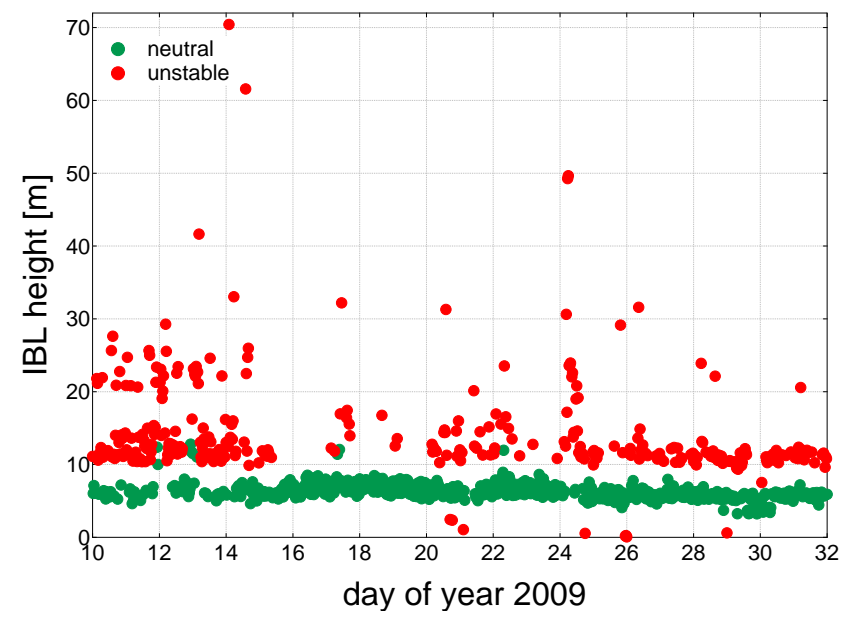

Fig. 5. Internal boundary layer (IBL) heights for neutral and unstable atmospheric layers for the second half of January 2009.

with $N_{i}$ being the number concentration, $D p_{i}$ being the diameter of the size channel $i$ and $\rho_{\mathrm{md}}$ being the particle density of mineral dust with $2.45 \mathrm{~g} \mathrm{~cm}^{-3}$. The value of the particle density was obtained by scanning electron microscopy (Kandler et al., 2009) for the Saharan Mineral Dust Experiment (SAMUM-1), which was conducted in Morocco in 2006. The integral over the whole size range gives the total mass concentration of mineral dust. Since the particle number size distribution was converted to volume equivalent diameters (cf. Eqs. 1 and 2), the resulting mass concentration is corrected for shape effects.
The error of this method is a combination of the errors of the mobility and aerodynamic particle number size distributions, the number fraction of mineral dust and the particle density. As described previously, the error of the particle number size distribution can be estimated to be about $15 \%$, which is the error of the APS. The uncertainty of the number fraction of mineral dust and the particle density is $15 \%$ and $2 \%$, respectively. With error propagation the total error for $M_{\text {mp }}$ results to $21 \%$.

\subsubsection{Mass concentration using the optical method $\left(M_{\mathrm{op}}\right)$}

It is assumed that mineral dust and soot are the only light absorbing particles in the Cape Verde region, and that the measured absorption spectra are a linear superposition of mineral dust and soot particle absorption. Therefore, the particle light absorption coefficient is given by

$\sigma_{\text {abs }}(\lambda)=M_{\text {soot }} \cdot \operatorname{MAC}_{\text {soot }}(\lambda)+M_{\text {md }} \cdot \operatorname{MAC}_{\text {md }}(\lambda)$,

where MACs are the mass absorption coefficients of the absorbers and $M_{\text {soot }}$ and $M_{\mathrm{md}}$ are the mass concentration of soot and mineral dust, respectively. The spectral run of the mass absorption coefficients of soot is generally proportional to the $\lambda^{-1}$ (Kirchstetter et al., 2004). In contrast, the mass specific absorption coefficient of mineral dust cannot be parameterized by an exponential law. During the SAMUM1 campaign, spectral absorption coefficients were measured by the SOAP (Müller et al., 2009) and mass concentrations were estimated from SMPS and APS measurements (Schladitz et al., 2009). For a period with high mass concentrations of mineral dust, average mass absorption coefficients were determined to be $\mathrm{MAC}_{\mathrm{md}}(450 \mathrm{~nm})=0.114 \mathrm{~m}^{2} \mathrm{~g}^{-1}$ and $\operatorname{MAC}_{\mathrm{md}}(650 \mathrm{~nm})=0.0198 \mathrm{~m}^{2} \mathrm{~g}^{-1}$. Mass absorption coefficients depend on the relative abundance of iron, which is the main absorbing species in the mineral dust. The relative iron abundance during this period was about $1 \%$ (Kandler et al., 2009). Considering the spectral run of the mass absorption coefficients of soot and mineral dust, the mass concentration of mineral dust can be calculated from measured absorption coefficients at the wavelength 450 and $650 \mathrm{~nm}$ by

$M_{\mathrm{md}}=\frac{\sigma(450 \mathrm{~nm})-\sigma(650 \mathrm{~nm}) \cdot \frac{650}{450}}{\mathrm{MAC}_{\mathrm{md}}(450 \mathrm{~nm})-\mathrm{MAC}_{\mathrm{md}}(650 \mathrm{~nm}) \cdot \frac{650}{450}}$.

It should be kept in mind that values for the mass absorption coefficients given in the text above are referenced to $1 \%$ relative abundance of iron. Thus, the derived mass concentrations using this method are referenced to a relative iron abundance of $1 \%$.

\subsubsection{Mass concentration using the gravimetrical $\operatorname{method}\left(M_{\mathrm{gr}}\right)$}

The $\mathrm{PM}_{10}$ mass concentration was determined gravimetrically by weighing the aluminum foils before and after 
sampling using a UMT-2 (Mettler-Toledo, Switzerland) microbalance with a reading precision of $0.1 \mu \mathrm{g}$ and a standard deviation of about $1 \%$. Before weighing, the foils were equilibrated for $48 \mathrm{~h}$ at constant temperature $\left(20 \pm 2{ }^{\circ} \mathrm{C}\right)$ and relative humidity $(52 \pm 5 \%)$ provided by a saturated sodium bisulfate solution.

The analysis of the impactor samples provides information about the $\mathrm{PM}_{10}$ mass concentrations of sea salt and non-sea salt ions, elemental and organic carbon. Mass concentrations of mineral dust were estimated from the difference of total mass and sea salt ion mass. Additionally, it was assumed that $10-15 \%$ of the total mass was water. Weighing and the chemical analyses of the impactor samples were carried out according to the methods described in Müller et al. (2010). The foils were stored in a refrigerator and transportation was done using cryogenic boxes below $-10^{\circ} \mathrm{C}$ to avoid chemical processing of organic material.

\subsection{Computation of mass deposition fluxes of mineral dust}

\subsubsection{Combining the micrometeorological method or the profile method, respectively, and the microphysical method $\left(F_{\mathrm{mm}, \mathrm{mp}}, \boldsymbol{F}_{\mathrm{pm}, \mathrm{mp}}\right)$}

The application of Eq. (3) for each diameter bin of the particle mass size distribution of mineral dust yields size-resolved mass fluxes of mineral dust $F_{i}$, and the total mass deposition flux of mineral dust $F_{\text {total }}$ can be obtained by summing over all size classes $i$ :

$$
F_{\text {total }}=\sum_{i=1}^{N} F_{i},
$$

with $N$ being the total number of diameter bins, which again have a logarithmic equidistant distance of 0.03 .

Error propagation of the errors for the $M_{\mathrm{mp}}(21 \%)$ and the micrometeorological method $(22 \%)$ or the profile method (22\%) yield a total error of $31 \%$ for the $F_{\mathrm{mm}, \mathrm{mp}}$ and $F_{\mathrm{pm}, \mathrm{mp}}$ method, respectively.

\subsubsection{Combining the micrometeorological method and the optical method $\left(F_{\mathrm{mm}, \mathrm{op}}\right)$}

Since the SOAP measurements only provide total, no sizeresolved, mass concentrations of mineral dust, a representative particle diameter to calculate the deposition velocity has to be found. A first attempt following Held et al. (2006) by using an effective deposition diameter (geometric mean diameter of the particle number size distribution) failed for this method, because it was developed to obtain a number deposition flux rather than a mass deposition flux. Therefore, the particle diameter of $2.25 \mu \mathrm{m}$, where $90 \%$ of the mass of the particle mass size distribution of mineral dust is reached for nearly the whole time period, was taken. The chosen diameter corresponds to a mean deposition velocity of $0.7 \mathrm{~mm} / \mathrm{s}$ over the whole period. For comparison, a size-weighted deposition diameter for the $F_{\mathrm{mm} \text {,mp }}$ method was calculated by dividing the total mass deposition flux by the total mass of mineral dust. This yields an average size-weighted deposition velocity of $0.8 \mathrm{~mm} / \mathrm{s}$ for the whole time period with a variance of $0.13 \mathrm{~mm} / \mathrm{s}$. Thus, the diameter where $90 \%$ of the mass of the particle mass size distribution of mineral dust is reached is a good estimate to calculate the deposition velocity.

Error propagation of the errors for the $M_{\mathrm{op}}(55 \%)$ and the micrometeorological method $(22 \%)$ yield a total error of $59 \%$ for the $F_{\mathrm{mm}, \mathrm{op}}$ method.

\subsubsection{Scanning electron microscopy $\left(F_{\text {SEM }}\right)$}

The mass of the individual particles sampled on the glassy carbon substrates (see Sect. 2.2.8) was summed up for (i) all particle sizes, (ii) particles smaller than $10 \mu \mathrm{m}$ projected area diameter, (iii) mineral dust particles, and (iv) mineral dust particles smaller than $10 \mu \mathrm{m}\left(m_{\mathrm{md}<10}\right)$. The information on mineral dust masses for particles smaller than $10 \mu \mathrm{m}$ diameter is used for comparison with the $\mathrm{PM}_{10}$ mass concentration measurements. Naturally, a systematic difference has to be expected, as in contrast to microscopy, $\mathrm{PM}_{10}$ mass concentration is defined by the aerodynamic particle diameter. Knowing the sampled mass of mineral dust $m_{\mathrm{md}}<10$, the area of analysis $A$ and the sampling time $t$, a deposition rate was calculated by

$F=\frac{m_{\mathrm{md}<10}}{A \cdot t}$.

The largest error of this method derives from an unknown aspiration and deposition efficiency of the sampling device for higher wind speeds. While the sampler is known to collect particle mass with an error of $20 \%$ with respect to reference methods at lower wind speeds (Dietze et al., 2006), a lower collection efficiency may occur at higher wind speeds due to particle re-entrainment from the substrate, turbulent deposition and interception at the inlet and the inner walls.

A second major source of uncertainty is the particle volume estimation from the 2-D geometry of the particles. If the particles are plate like, this may lead to an overestimation of mass concentrations by this method. Unfortunately, there is no thorough information available on the 3-D particle shape of Saharan mineral dust, which would allow estimating the uncertainty in in situ measured volume concentration. For remote sensing a spheroidal model can be used as a replacement for non-spherical particles as shown in Dubovik et al. (2006). Similar investigations for in situ techniques would require a detailed analysis of SEM pictures and in situ measured particle size distributions to get a statistics on shape factors, what is out of the scope of this manuscript.

Minor sources of uncertainty are the particle cross-section determination from the backscatter electron image (applied lateral resolution of $75 \mathrm{~nm}$ ). The separation of the particles 
into mineral dust and sea salt based on the chemical information has a very low uncertainty, as these particle types have a largely different elemental composition and can be distinguished easily. Finally, a minor source of uncertainty derives from the counting statistics. As each sample comprises at least 700 particles, the relative error is less than $4 \%$.

From this consideration, an overall uncertainty of $50 \%$ in total mass concentration and $30 \%$ for the concentration of particles smaller than $10 \mu \mathrm{m}$ projected area diameter is estimated.

\subsubsection{Regional mineral dust transport model $\left(F_{\text {model }}\right)$}

Saharan mineral dust transport and deposition were simulated for the intensive SOPRAN campaign in January 2009 using the mineral dust model version of COSMO-MUSCAT (Heinold et al., 2007, 2011). The regional model system consists of the operational forecast model COSMO (Steppeler et al., 2003) of the German weather service (Deutscher Wetterdienst; DWD) and the online-coupled 3-D chemistry transport model MUltiScale Chemistry Aerosol Transport model (MUSCAT) (Wolke et al., 2004; Renner and Wolke, 2010). Mineral dust emission calculations are based on the scheme by Tegen et al. (2002), which takes surface properties (vegetation, surface roughness, soil texture) and the location of potential mineral dust sources derived from Meteosat Second Generation (MSG) satellite observations (Schepanski et al., 2007) into account. Mineral dust emission, transport, and deposition are simulated using meteorological and hydrological fields from COSMO including the computation of the direct radiative effect of mineral dust on atmospheric dynamics (Helmert et al., 2007). The model predicted mineral dust is transported in five independent particle size classes between 0.2 and $50 \mu \mathrm{m}$ diameter assuming spherical particles and a log-normal size distribution for each size bin. For this study, the first three particle size classes up to a diameter of $5.2 \mu \mathrm{m}$ were used for comparison with measurements. The mineral dust particles are removed from the atmosphere by dry and wet deposition. The parameterization of dry deposition follows Zhang et al. (2001) as described in paragraph 3.1. The density of mineral dust is assumed to be $2.65 \mathrm{~g} \mathrm{~cm}^{-3}$ in this model.

For the mineral dust transport and deposition simulations, a horizontal grid resolution of $28 \mathrm{~km}$ was used. The vertical grid has 40 layers with the first layer centered around $38 \mathrm{~m}$ above surface. The model domain, whose south-west and north-east corner is located at $0.2^{\circ} \mathrm{N}, 32.3^{\circ} \mathrm{W}$ and $41.1^{\circ} \mathrm{N}$, $32.9^{\circ} \mathrm{E}$, respectively, covers relevant parts of the Saharan desert and the tropical North Atlantic Ocean (Fig. 9). Initialization and large-scale meteorological forcing of COSMOMUSCAT are based on $6 \mathrm{~h}$ analysis fields from the global model GME (Majewski et al., 2002). The simulations were carried out in cycles with a re-initialization every 48 hours in order to keep the meteorology of the regional model close to the analysis data.

\section{Results}

Three events with high mass concentrations of mineral dust were observed at the Cape Verde Islands in January 2009: day of year (DOY) 12-16, 21-27, and 29-32. Figure 6 shows a composite of the meteorological situations of the three periods. The wind is indicated as vector for wind velocities larger than $1 \mathrm{~m} \mathrm{~s}^{-1}$ and the dark grey lines present the geopotential height, both in the $925 \mathrm{hPa}$ level. Both fields are taken from the ECMWF ERA-Interim reanalysis data set (Dee et al., 2011). Furthermore, dust source activation frequencies retrieved from MSG SEVIRI IR dust index images as described by Schepanski et al. $(2007,2009 b, 2012)$ are shown. The CVAO is indicated with a red point. Calculated 10-day back trajectories ending at the CVAO showed the same pathway as can be seen from the wind vectors, so they are not shown separately.

The synoptic situation during the first mineral dust event was characterized by an upper cut-off low over the southern Iberian Peninsula and northern Morocco. At sea-level (Fig. 6a), a region of low pressure occurred over Tunisia and a smaller low pressure zone emerged across central Algeria most likely due to lee effects at the Atlas mountain chain. Strong surface winds related to a low-level cold front mobilized mineral dust in Algeria. Further dust mobilization took place over northern Mali and Mauretania, as can be seen from the dust source activation frequency in Fig. 6a. The frontal winds together with the north-easterly trade winds subsequently transported the mineral dust from the western coast of Africa towards the Cape Verde Islands.

Different meteorological conditions led to strong mineral dust emissions during the second event (Fig. 6b). On DOY 21 and 22, the extensions of the Azores High moved southwestwards and reached the West African coast. To the east an upper level trough (not shown in the Figure) spread from the mid-latitudes to northwestern Africa, and an associated winter cyclone formed with the extensions reaching northeast Africa. The related strong frontal winds caused mineral dust emissions over northeastern Algeria and western Libya. During the second part of this mineral dust event, the high pressure zone strengthened and further extended over northern Africa. As a result a strong south-north pressure gradient prevailed over the Sahel and southern Sahara. Very intense mineral dust activation was observed over northwest Niger and additional mineral dust sources were activated in Morocco and Mauritania. The mineral dust from the latter regions (similar to the first event) was transported westwards at the southern flank of the subtropical high.

Similar meteorological conditions but with different dust source activation regions were observed for the third event at the end of the month (Fig. 6c). Mineral dust emissions and transport were caused by strong Harmattan winds associated with the intensification of the high pressure system over the Sahara. The observed mineral dust at CVAO originated not 

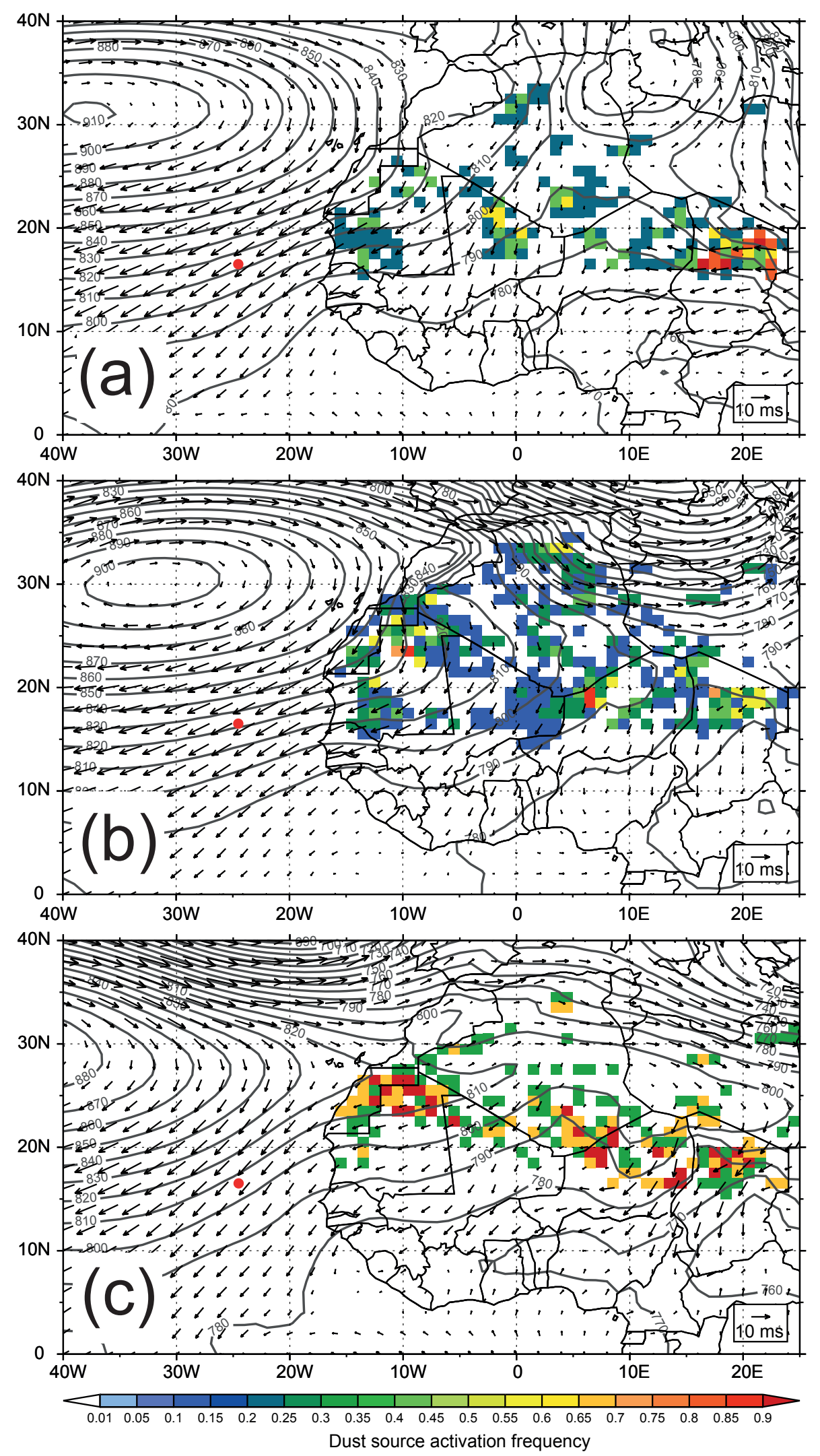

Fig. 6. Dust source activation frequency retrieved from MSG SEVIRI IR dust index images (shaded colors) for the three events from DOY 12-16, 21-27 and 29-31, overlayed by ECMWF ERA-Interim $925 \mathrm{hPa}$ wind fields for wind velocities larger than $1 \mathrm{~ms}-1$ (vectors) and $925 \mathrm{hPa}$ geopotential (contours). The red point indicates the location of the Cape Verde atmospheric observatory. 


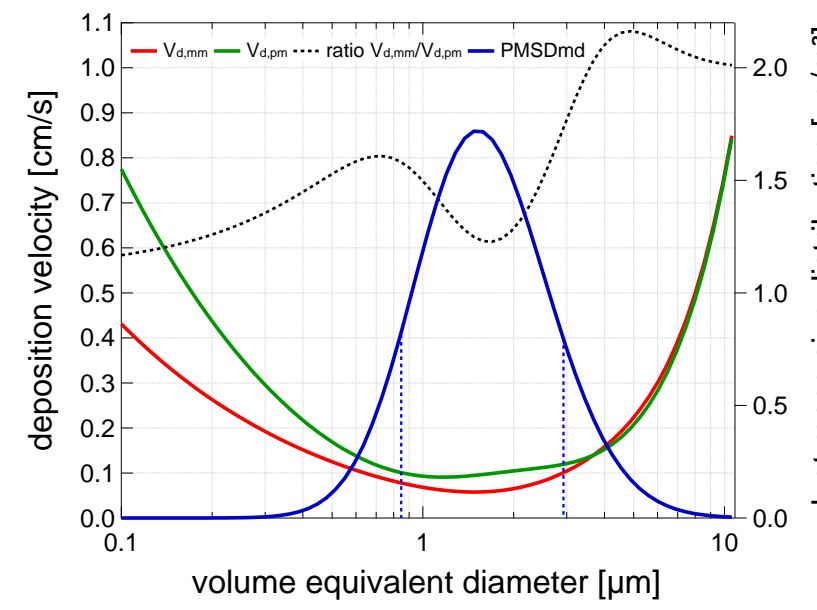

Fig. 7. Comparison of the averaged deposition velocities (January 2009) obtained by the ultra-sonic anemometer (red line) and two 2$\mathrm{D}$ anemometers (green line) using the micrometeorological method $\left(v_{\mathrm{d}, \mathrm{mm}}\right)$ and profile method $\left(v_{\mathrm{d}, \mathrm{pm}}\right)$, respectively (left axis). The ratio of both velocities (dotted black line, left axis) and the particle mass size distribution of mineral dust (PMSDmd, blue line) are also shown (right axis). The dotted blue lines show the points, where 10 and $90 \%$ of the cumulated mass of mineral dust is reached.

only from the western coast of Africa (Morocco and Mauritania), but also from Algeria.

\subsection{Deposition velocity}

Figure 7 shows the mean value of the deposition velocity of the micrometeorological and the profile method, the ratio between both methods and the averaged particle mass size distribution of mineral dust for January 2009. The correlation coefficient between both deposition velocities is $R^{2}=0.95$ (not shown here). As can be seen, the least agreement between the two methods occurs for the smallest particle diameters $(0.1-0.3 \mu \mathrm{m})$ with a ratio of both curves of less than 0.7. However, mineral dust particles are usually larger than about $0.2 \mu \mathrm{m}$ (Kaaden et al., 2009; Kandler et al., 2009), which is also confirmed by the observed particle mass size distribution of mineral dust. Therefore, the size range smaller than $0.3 \mu \mathrm{m}$ can be neglected here. In the size range between 0.84 and $3.0 \mu \mathrm{m}(10 \%$ and $90 \%$ of the cumulated mass concentrations), the ratio of both velocities varies between 0.6 and 0.8. Since no other information on the calculation of the error for both methods exists, the average ratio in this size range is used to determine an uncertainty of both velocities, which is $29 \%$. For particles larger than $3.0 \mu \mathrm{m}$, the discrepancies between both methods become negligible. Duce et al. (1991) gave a value of $1.0 \mathrm{~cm} \mathrm{~s}^{-1} \pm$ a factor of 3 for supermicrometer crustal particles. The mean deposition velocity for both methods in the particle range of $1-10 \mu \mathrm{m}$ is $0.2 \mathrm{~cm} \mathrm{~s}^{-1}$ and thus 5 times smaller than the value given by Duce et al. (1991). However, in the particle size range between 1 and $4 \mu \mathrm{m}$, gravitational settling is not the dominant

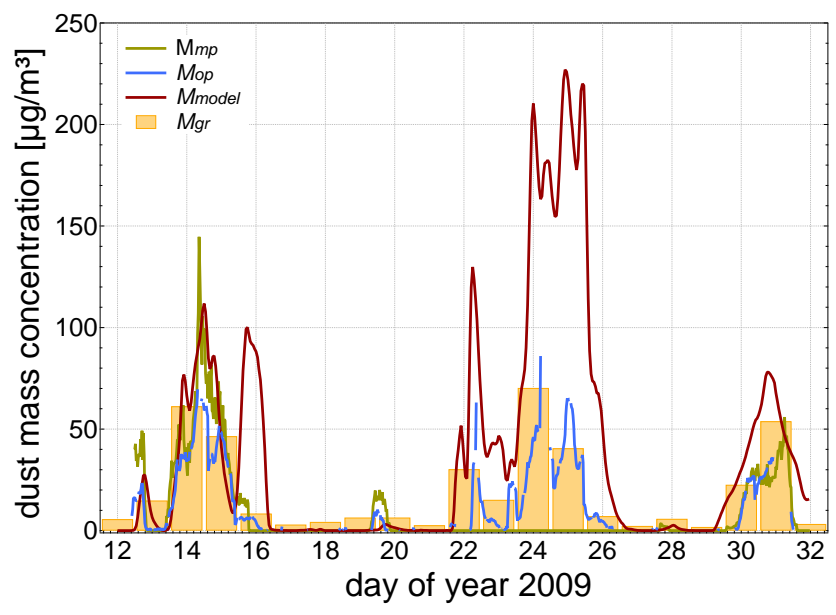

Fig. 8. Time series of the mass concentrations of mineral dust obtained from the particle mass size distribution of mineral dust $\left(M_{\mathrm{mp}}\right)$, from optical absorption spectroscopy $\left(M_{\mathrm{op}}\right)$, from the regional dust transport model $\left(M_{\text {model }}\right)$ and from Berner impactor measurements $\left(M_{\mathrm{gr}}\right)$ for the second half of January 2009.

removal process as described in Duce et al. (1991). With increasing particle size, also the deposition velocity increases reaching a value of $0.83 \mathrm{~cm} \mathrm{~s}^{-1}$ at $10 \mu \mathrm{m}$ which is close to $1.0 \mathrm{~cm} \mathrm{~s}^{-1}$.

For most particle diameters, the deposition velocity of the profile method is above the velocity of the micrometeorological method. The consequence for the resulting mass deposition flux of mineral dust is that fluxes obtained by the profile method will be higher compared to those obtained by the micrometeorological method.

\subsection{Mass concentration of mineral dust}

Before presenting dust mass deposition fluxes, the mass concentrations of mineral dust obtained from the different methods are compared. Figure 8 shows time series of total mass concentrations of mineral dust from the microphysical and optical measurements $\left(M_{\mathrm{mp}}\right.$ and $\left.M_{\mathrm{op}}\right)$ and regional transport simulations $\left(M_{\text {model }}\right)$ together with daily values from the Berner impactor $\left(M_{\mathrm{gr}}\right)$. Between DOY 22 and 27, no values for $M_{\mathrm{mp}}$ are available, because the H-DMA-APS did not work during this period, and therefore no number fractions of mineral dust could be determined.

The time series of the dust concentration at the CVAO shows three main peaks during the dust outbreaks on DOY 14,24 , and 30 to 31 . The maximum and mean values for the three events are given in Table 2. The highest value is given by the model for the second event with $227 \mu \mathrm{g} \mathrm{m}^{-3}$ and is close to the maximum value of $250 \mathrm{\mu g} \mathrm{m}^{-3}$ given by Ginoux et al. (2001) for mass concentrations of mineral dust in the boundary layer in the Northern Hemisphere (e.g., the Sahara and Sahel region). Calculating the ratio of the maximum and mean values for each method and event (not shown) yields a 
Table 2. Mean and maximum values for the mass concentration of mineral dust obtained during the three main dust events are in units of $\mu \mathrm{g} \mathrm{m} \mathrm{m}^{-3}$.

\begin{tabular}{lcccccccc}
\hline & \multicolumn{2}{c}{$M_{\mathrm{mp}}$} & \multicolumn{2}{c}{$M_{\mathrm{op}}$} & \multicolumn{2}{c}{$M_{\text {model }}$} & \multicolumn{2}{c}{$M_{\mathrm{gr}}$} \\
& Mean & Max & Mean & Max & Mean & Max & Mean & Max \\
\hline Event 1 & 35 & 144 & 22 & 70 & 40 & 112 & 27 & 62 \\
Event 2 & - & - & 20 & 86 & 80 & 227 & 28 & 70 \\
Event 3 & 15 & 56 & 17 & 36 & 35 & 78 & 20 & 54 \\
\hline
\end{tabular}

factor larger than 3 for $M_{\mathrm{mp}}$ and $M_{\mathrm{op}}$ (except event 3) and a factor smaller than 3 for $M_{\text {model }}$ and $M_{\mathrm{gr}}$. The better time resolution of the instruments of the first two methods explains this finding. All four methods agree well on the temporal evolution of the mass concentration of mineral dust. Mass concentrations of mineral dust obtained by the SOAP are mostly lower than $M_{\mathrm{mp}}$, which is due to the fact that the SOAP retrieval uses the mass fraction of iron oxide in the mineral dust particles. To calculate the mass concentration of mineral dust, a constant mass fraction of iron oxide was assumed (Müller et al., 2009), which may lead to an over- or underestimation of the mass concentration depending on the actual iron content of dust particles.

The Berner impactor measurements are considered as an independent technique to compare with the atmospheric aerosol concentration from physical measurements. For direct comparison with the daily values of the Berner impactor (measured from noon to noon), also daily values for $M_{\mathrm{mp}}$ and $M_{\text {op }}$ were calculated when at least $65 \%$ of the data for this day were available. The deviation between $M_{\mathrm{gr}}$ and $M_{\mathrm{mp}}$ is $20 \%$, while the deviation between $M_{\mathrm{gr}}$ and $M_{\mathrm{op}}$ is $40 \%$ (not shown here). This shows that the mass concentration from measurements of the particle mass size distribution of mineral dust is comparable to the mass concentration obtained by Berner measurements, while the mass concentration obtained by absorption photometer measurements underestimates it by a factor of approximately 1.7. Therefore, the time- and size-resolved measurements of mineral dust concentration $\left(M_{\mathrm{mp}}\right)$ are used as reference in the following.

The COSMO-MUSCAT results overestimate the measured mass concentration in general. Only for dust event 1 , the modeled dust concentrations at surface level are very similar to the measured ones. For the second dust event, the model is up to a factor of 4 too high compared to the measurements. It should be kept in mind, that those comparisons are generally problematic, since local measurements, which represent the conditions at a single point, may not be entirely representative of a whole model grid cell with $28 \mathrm{~km}$ grid spacing. Although a thorough model evaluation is beyond the scope of this study, potential reasons for the overestimation of the second dust event are discussed in the following.

Discrepancies can be identified by comparing modelderived aerosol optical depth (AOD) with the AOD from MODIS satellite observations. Figure 9 shows the modeled and observed AOD over West Africa and the Cape Verde islands on DOY 24-25. As described above, the mineral dust emissions during this event resulted from a winter cyclone and related strong frontal surface winds over northern Africa. Here, the model apparently overestimated the mineral dust emission in eastern Algeria and western Libya as result of an overestimated cyclone development, which results in a too strong dust transport towards the Cape Verdes (cf. Figure 9a and $9 \mathrm{~b}$ ). The high values of observed (MODIS) AOD over and west of the Gulf of Guinea were mainly due to smoke aerosol from biomass burning in southern West Africa, which was not considered in this model version. The MODIS AOD in this region also included mineral dust from the Bodélé depression and minor dust sources to the west, which were well reproduced by COSMO-MUSCAT. In addition, large uncertainties in the mineral dust prediction occur due to strong horizontal gradients in the actual dust distribution that cannot be resolved by the model. A misrepresentation of the transport height may also explain the discrepancies, which in particular is assumed to be the reason during the third dust outbreak (not shown).

Figure 10 shows the correlation between $M_{\mathrm{mp}}$ and $M_{\mathrm{op}}$ or $M_{\text {model }}$, respectively. The correlation between $M_{\mathrm{mp}}$ and $M_{\mathrm{op}}$ shows an underestimation of $M_{\mathrm{op}}$ of $30 \%$ compared to $M_{\mathrm{mp}}$. Although the correlation coefficient is high with $R^{2}=0.80$, the problematic of the SOAP measurement regarding a constant iron oxide value leads to this uncertainty. As expected, the correlation of $M_{\mathrm{mp}}$ with $M_{\text {model }}$ is worse with $R^{2}=0.41$. The scatter of the data points is larger, in particular, for moderate and weak dust concentrations, which indicates an overand underestimation of mineral dust concentrations, respectively. For a relatively homogenous mineral dust layer over the entire grid cells around the single point measurement, the quantitative agreement is within $87 \%$ for the mean values and $70 \%$ for the maximum values between model and measurement.

\subsection{Dust mass deposition flux}

The mass deposition fluxes of mineral dust are presented as weekly mean values obtained with the different methods. The data was merged into groups that cover the sampling time periods of the passive samplers. As opposite to the time series that show dust concentrations until the last day of January 


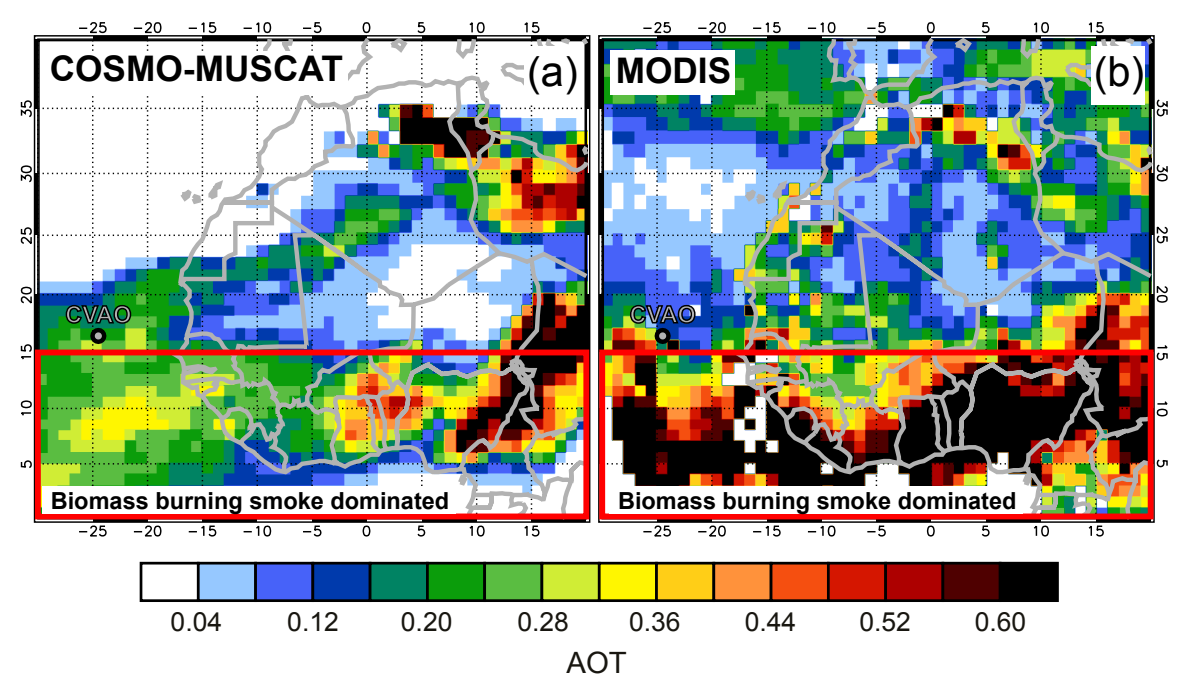

Fig. 9. Horizontal distribution of Saharan dust during the period 24-25 January 2009. Shown are maps of (a) modeled aerosol optical depth (AOD) $(550 \mathrm{~nm})$ and (b) a composite of MODIS AOD at $550 \mathrm{~nm}$ over sea and the MODIS Deep Blue AOD at $550 \mathrm{~nm}$ over land. The values of optical depth are time averages ( 2 fields of observation at 10:30 LT for Modis overpass and 10:00 LT for the model). Latitudes up to $15^{\circ} \mathrm{N}$ have a frame, as in this region the MODIS AOD is dominated by biomass burning aerosol, which is not considered in the model simulations.
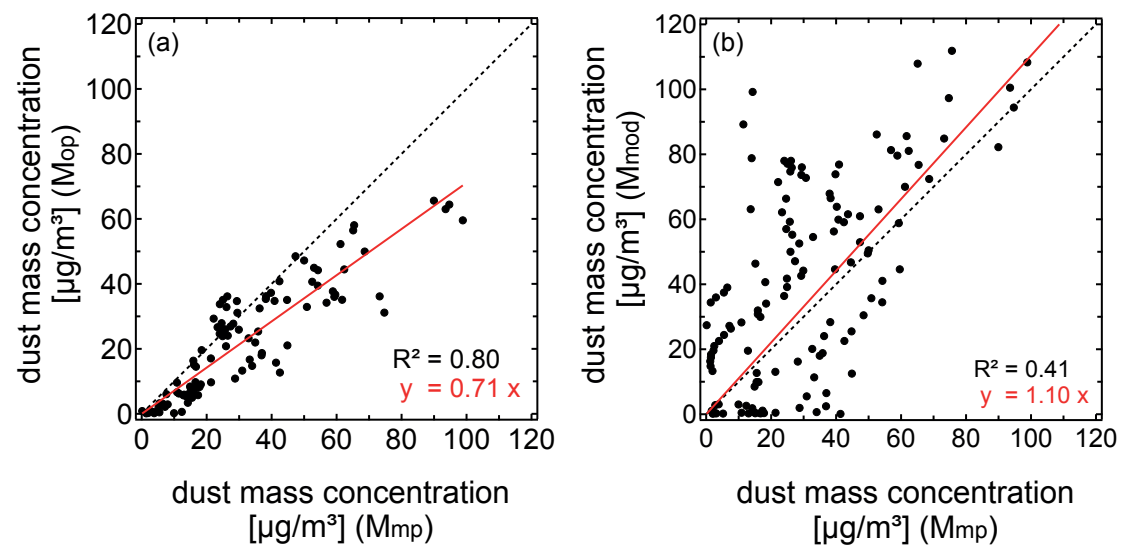

Fig. 10. Correlation plots of the mass concentrations of mineral dust obtained from optical absorption spectroscopy measurements $\left(M_{\mathrm{op}}\right)$ and a regional dust transport model $\left(M_{\text {model }}\right)$ compared to the mass concentrations of mineral dust obtained from the particle mass size distribution of mineral dust $\left(M_{\mathrm{mp}}\right)$.

(DOY 31.95), these data also include dust free days of February.

\section{Period 1: DOY 7.5 to 15.5}

Period 2: DOY 15.5 to 22.5

Period 3: DOY 22.5 to 29.5

Period 4: DOY 29.5 to 36.5

Figure 11 presents the weekly mass deposition fluxes of mineral dust including error bars that were introduced when describing the methods and also showing the mean values in numbers below the bars. The relative errors for the different methods are $31 \%$ for $F_{\mathrm{mm}, \mathrm{mp}}, 31 \%$ for $F_{\mathrm{pm}, \mathrm{mp}}, 59 \%$ for
$F_{\mathrm{mm}, \mathrm{op}}$, and $30 \%$ for $F_{\mathrm{SEM}}$. There are no errors given for the model, since only ensemble simulations provide a basis for a statistical analysis. The main source of model errors is the representation of dust-generating surface winds and soil properties in the source region of mineral dust. Depending on whether a model grid cell is activated as dust source or not, theoretically, the error can be up to $100 \%$ (Laurent et al., 2008). No values could be shown for the $F_{\mathrm{pm} \text {,mp }}$ method for period 2, since anemometer measurements were available only in one height. Results for the $F_{\mathrm{mm}, \mathrm{mp}}$ and the $F_{\mathrm{pm}, \mathrm{mp}}$ methods are not discussed for Period 3, since too many data of mass concentration of mineral dust were missing due to the absence of H-DMA-APS measurements. 
Table 3. Mean and maximum values for the mass deposition flux of mineral dust obtained during the three main dust events are in units of $\mathrm{ng} \mathrm{m}^{-2} \mathrm{~s}^{-1}$.

\begin{tabular}{lcccccccc}
\hline & \multicolumn{2}{c}{$F_{\text {mm,mp }}$} & \multicolumn{2}{c}{$F_{\text {pm,mp }}$} & \multicolumn{2}{c}{$F_{\text {mm,op }}$} & \multicolumn{2}{c}{$F_{\text {model }}$} \\
& Mean & Max & Mean & Max & Mean & Max & Mean & Max \\
\hline Event 1 & 40 & 137 & 60 & 103 & 16 & 64 & 56 & 125 \\
Event 2 & - & - & - & - & 14 & 71 & 111 & 275 \\
Event 3 & 16 & 43 & 17 & 38 & 13 & 33 & 44 & 94 \\
\hline
\end{tabular}

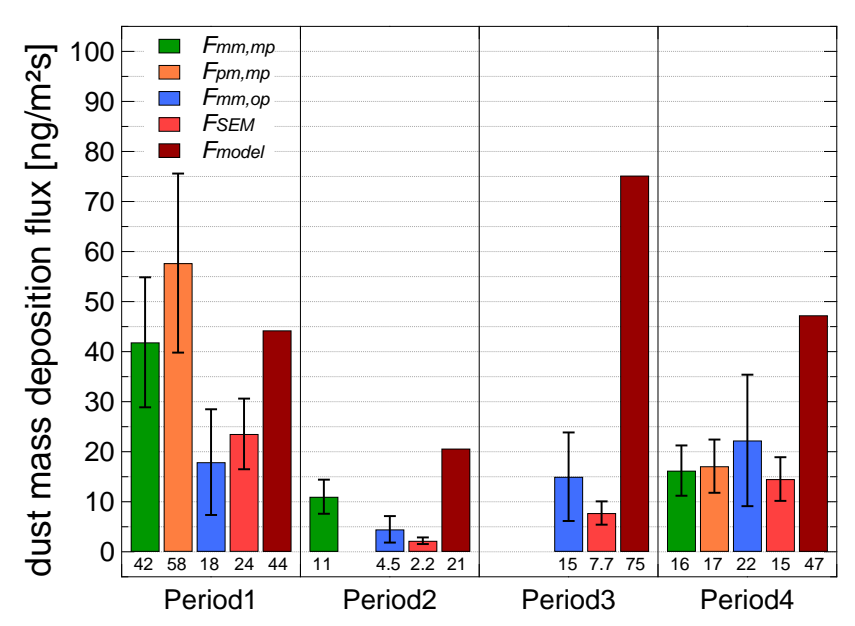

Fig. 11. Weekly averages of the mass deposition flux of mineral dust for the different measurement techniques combining micrometeorological method and mass concentrations of mineral dust obtained by measurements of the particle mass size distribution of mineral dust $\left(F_{\mathrm{mm}, \mathrm{mp}}\right)$, the profile method and mass concentrations of mineral dust obtained by measurements of the particle mass size distribution of mineral dust $\left(F_{\mathrm{pm}, \mathrm{mp}}\right)$, the micrometeorological method and mass concentrations of mineral dust obtained from optical absorption spectroscopy measurements $\left(F_{\mathrm{mm}, \mathrm{op}}\right)$, scanning electron microscopy analysis of passive sampled mineral dust particles $\left(F_{\mathrm{SEM}}\right)$ and the output of a regional dust transport model $\left(F_{\text {model }}\right)$. Error bars show the percentage error of the individual methods. Below the bars, the total values are added.

In general it can be seen that the lowest values were obtained from the $F_{\mathrm{mm} \text {,op }}$ and the $F_{\mathrm{SEM}}$ methods. Reasons for the lower-end values of the $F_{\text {SEM }}$ can be explained by the high wind speed (median of $7.3 \mathrm{~m} \mathrm{~s}^{-1}$ ) that is always observed on top of the tower (Carpenter et al., 2010), which may yield a lower collection efficiency of the Passive-2 sampler. For the investigated period, the mean wind velocity was even found to be $10.4 \mathrm{~m} \mathrm{~s}^{-1}$. Furthermore, as explained above, the volume estimation of the particles from a 2-D image may cause large errors. The low value for the $F_{\mathrm{mm} \text {,op }}$ method may be based on a too low mass absorption coefficient for mineral dust and the difficulty to find a representative diameter for calculating the deposition velocity. One exception can be found for period 4, where all values (except that for the model) are close together. A slight change in the meteorological situation may explain the better fit of the $F_{\text {SEM }}$ method, since the wind velocity for this period slightly decreased to $9.6 \mathrm{~m} \mathrm{~s}^{-1}$. As could be seen from the mass concentration measurements, the SOAP results fitted better with the others within the last dust event. This result could suggest that the air masses are from a different source region compared to the first dust event, and that the iron oxide value could be different between the third and the first period. These findings agree with the meteorological situation introduced at the beginning of this chapter ("The observed mineral dust at CVAO originated not only from the western coast of Africa (Morocco and Mauritania), but also from Algeria.").

Comparable with the mass concentration measurements, the model results mainly overestimate the total mass deposition flux of mineral dust for nearly the whole time except for period 1 . The reasons are the same as discussed above like overestimated dust emissions over Algeria and western Libya and the unresolved gradient in the horizontal dust plume as well as a misrepresentation of the transport height.

There are two periods, where the $F_{\mathrm{mm}, \mathrm{mp}}$ and the $F_{\mathrm{pm}, \mathrm{mp}}$ methods are directly comparable. In period 1 , the $F_{\mathrm{pm}, \mathrm{mp}}$ method shows higher values compared to the $F_{\mathrm{mm}, \mathrm{mp}}$ which may be due to an overestimation of the deposition flux of the profile method. Both values agree for period 4 which leads again to the assumption, that a slight change in meteorology seems to have occurred since the deposition velocities for this period must be similar. The assumption behind this is that the atmosphere was in a state that fulfills the requirements for the logarithmic wind law better (e.g., horizontal homogeneity and stationarity).

A time series of the mass deposition flux of mineral dust is presented in Fig. 12. This figure looks very similar to the one for the mass concentrations of mineral dust, since this parameter serves as input for the deposition flux. Table 3 summarizes the mean and the maximum values for the three dust events. Similar to the results above, the first dust event shows the $F_{\text {mm,op }}$ method having the lowest value and the other three methods lying closer together. For dust event two, the model results are very high and for the third dust event, the measurements lie close together but the model overestimating the measurements by a factor of up to three in the mean and the maximum values. 
Table 4. Overview over dust deposition fluxes (of particles larger or smaller than $10 \mu \mathrm{m}-\mathrm{PM}_{10}$ ) obtained within this study (combination of the micrometeorological and the microphysical method $\left(F_{\mathrm{mm}, \mathrm{mp}}\right)$, the profile and the microphysical method $\left(F_{\mathrm{pm}, \mathrm{mp}}\right)$, the micrometeorological and the optical method $\left(F_{\mathrm{mm}, \mathrm{op}}\right)$, scanning electron microscopy $\left(F_{\mathrm{SEM}}\right)$ and the output of a regional dust transport model $\left.\left(F_{\text {model }}\right)\right)$ and compared to literature. All fluxes present deposition fluxes at the area of the tropical northeast Atlantic Ocean.

\begin{tabular}{lcccc}
\hline Name & Particle size & Time frame & Deposition & Dust deposition flux ng $\mathrm{m}^{-2} \mathrm{~s}^{-1}$ \\
\hline$F_{\mathrm{mm}, \mathrm{mp}}$ & $<\mathrm{PM}_{10}$ & Jan 2009 & dry & 25 \\
$F_{\text {pm,mp }}$ & $<\mathrm{PM}_{10}$ & Jan 2009 & dry & 29 \\
$F_{\text {mm,op }}$ & $<\mathrm{PM}_{10}$ & Jan 2009 & dry & 13 \\
$F_{\text {SEM }}$ & $<\mathrm{PM}_{10}$ & Jan 2009 & dry & 47 \\
$F_{\text {model }}$ & $<\mathrm{PM}_{10}$ & Jan 2009 & dry & $50-100$ \\
Zender et al. (2003) & $<\mathrm{PM}_{10}$ & 1990-1999 10 yr mean & dry & $320-640$ \\
Mahowald et al. (2005) & $>\mathrm{PM}_{10}$ & model composite of $>10 \mathrm{yr}$ & dry and wet & $230-270$ \\
Schepanski et al. (2009a) & $>\mathrm{PM}_{10}$ & Jan 2007 & dry & \\
\hline
\end{tabular}

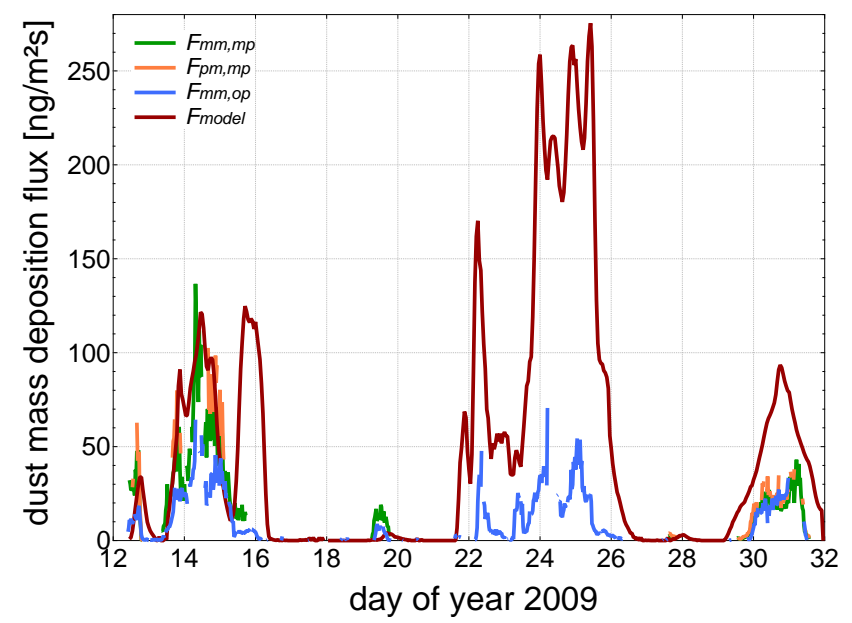

Fig. 12. Time series of the mass deposition flux of mineral dust combining micrometeorological method and mass concentrations of mineral dust obtained by measurements of the particle mass size distribution of mineral dust $\left(F_{\mathrm{mm}, \mathrm{mp}}\right)$, the profile method and mass concentrations of mineral dust obtained by measurements of the particle mass size distribution of mineral dust $\left(F_{\mathrm{pm}, \mathrm{mp}}\right)$, the micrometeorological method and mass concentrations of mineral dust obtained from optical absorption spectroscopy measurements $\left(F_{\mathrm{mm}, \mathrm{op}}\right)$ and the output of a regional dust transport model $\left(F_{\text {model }}\right)$ obtained for the second half of January 2009.

Scatter plots allow a better quantitative comparison among the different methods and are presented in the following. Here, the $F_{\mathrm{mm} \text {,mp }}$ method is considered as reference, as ultrasonic wind speed observations provide the most accurate information on turbulent mixing and measurements of the particle mass size distribution of mineral dust represent atmospheric mass concentrations of mineral dust best (see Sect. 4.2). In Fig. 13a, the fluxes from the $F_{\mathrm{mm}, \mathrm{mp}}$ and the $F_{\mathrm{pm}, \mathrm{mp}}$ method are compared, for which a correlation factor of $R^{2}=0.92$ is obtained. The flux obtained by the $F_{\mathrm{pm}, \mathrm{mp}}$ method is about $40 \%$ larger than the flux obtained by the $F_{\mathrm{mm} \text {,mp }}$ method. This can be explained by the larger val- ues (up to $30 \%$ ) of the deposition velocity for the profile method compared to the micrometeorological method in the diameter size range up to $4 \mu \mathrm{m}$. The comparison between the $F_{\text {mm,mp }}$ and $F_{\text {mm,op }}$ method shows an acceptable correlation, with a correlation coefficient of $R^{2}=0.71$ (Fig. 13b). Due to the fact that the mass concentration of mineral dust from the SOAP is underestimated, also the mass deposition flux of mineral dust obtained by the $F_{\mathrm{mm} \text {,op }}$ method is about $40 \%$ lower than that obtained by the $F_{\mathrm{mm} \text {,mp }}$ method. A weak correlation is only found between the $F_{\mathrm{mm}, \mathrm{mp}}$ method and the model with $R^{2}=0.37$ (Fig. 13c). Again, this is mainly due to the overestimation of the second dust event and the fact, that the model provides a homogeneous mineral dust distribution over the grid cell of $28 \mathrm{~km}$, while the measurements were performed at a single point. In addition, a minor reason may be the difference in density of mineral dust particles, which are assumed in the model $\left(2.65 \mu \mathrm{g} \mathrm{cm}^{-3}\right)$ and for the deposition flux calculation $\left(2.45 \mu \mathrm{g} \mathrm{cm}^{-3}\right)$.

The total deposition fluxes for January 2009 are summarized in Table 4. All measured and modeled mass deposition fluxes are of the same order of magnitude ranging between 12 and $47 \mathrm{ng} \mathrm{m}^{-2} \mathrm{~s}^{-1}$. Furthermore, the data were compared to literature values obtained from global and regional model simulations for different time periods for the Cape Verde region. Zender et al. (2003) give a $10 \mathrm{yr}$ average mass deposition flux of mineral dust of $50-100 \mathrm{ng} \mathrm{m}^{-2} \mathrm{~s}^{-1}$ for particles smaller than $10 \mu \mathrm{m}$ aerodynamic diameter, which is nearly double the flux measured in this study. The comparison with the global model output of Mahowald et al. (2005) presenting a $10 \mathrm{yr}$ average of three reanalysis-based models combined with sediment trap and in situ observations, and the regional model output of Schepanski et al. (2009a) for January 2007 show one order of magnitude higher mass deposition fluxes of mineral dust than presented within this study. However, the deposition flux given by the models include particles larger than $10 \mu \mathrm{m}$, which is only partly comparable to results in this study, since particles larger than $10 \mu \mathrm{m}$ may contribute significantly to the mass concentration of mineral dust. The discrepancies to the findings by Mahowald et al. (2005) can 


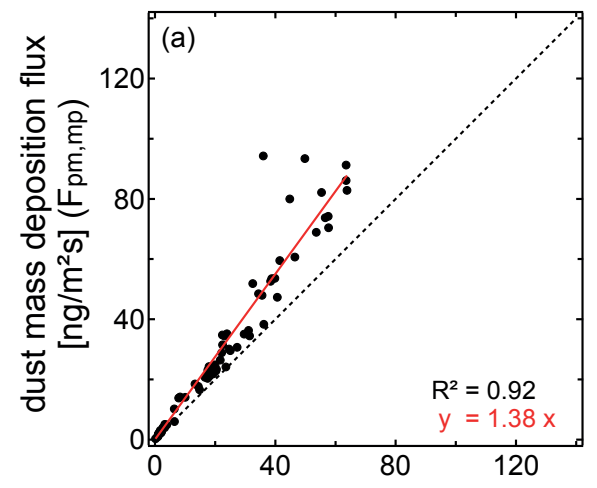

dust mass deposition flux $\left[\mathrm{ng} / \mathrm{m}^{2} \mathrm{~s}\right]\left(\mathrm{Fmm}_{\mathrm{mp}}\right)$

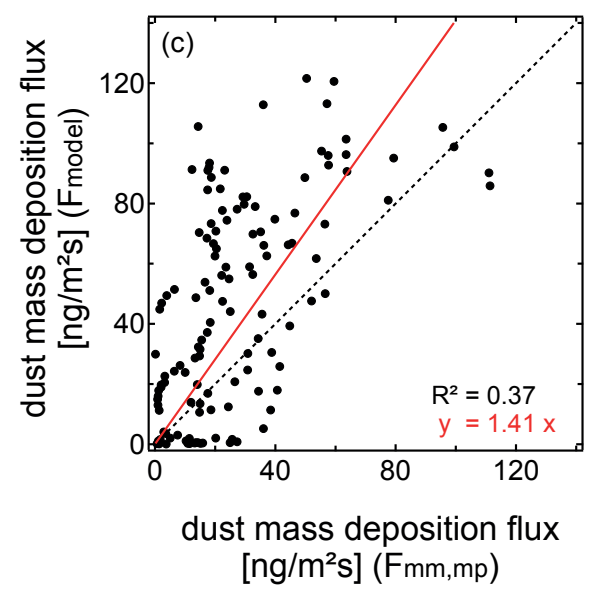

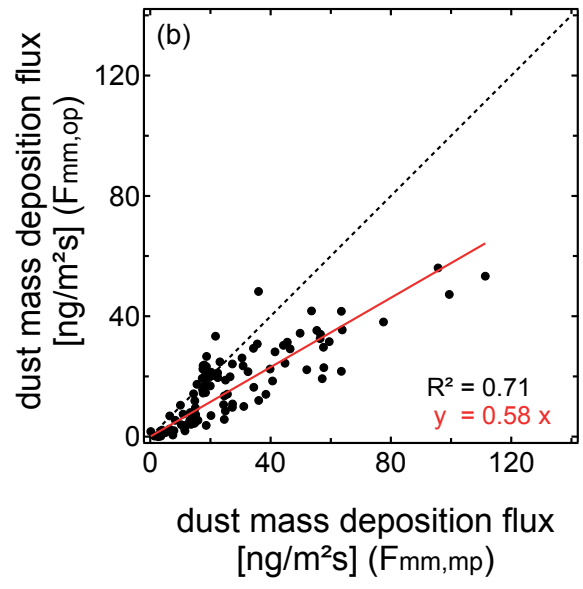

$\left[\mathrm{ng} / \mathrm{m}^{2} \mathrm{~s}\right](\mathrm{Fmm}, \mathrm{mp})$

Fig. 13. Correlation plots of the mass deposition fluxes of mineral dust obtained from the combination of the profile method and mass concentration of mineral dust obtained by measurements of the particle mass size distribution of mineral dust $\left(F_{\mathrm{pm}, \mathrm{mp}}\right)$, the micrometeorological method and mass concentrations of mineral dust from optical absorption spectroscopy measurements $\left(F_{\mathrm{mm}, \mathrm{op}}\right)$ and a regional dust transport model $\left(F_{\text {model }}\right)$ compared to the mass deposition flux of mineral dust obtained from the combination of the micrometeorological method and mass concentration of mineral dust obtained by measurements of the particle mass size distribution of mineral dust $\left(F_{\mathrm{mm}, \mathrm{mp}}\right)$.

also be explained by the fact that they also consider wet deposition, which accounts for $30 \%$ of the total deposition (Laurent et al., 2010). Mahowald et al. (2005) state an uncertainty factor of 10 for their deposition flux of mineral dust.

\section{Summary and conclusions}

In this study, different techniques to obtain dry mass deposition fluxes of Saharan mineral dust to the tropical northeast Atlantic Ocean were presented. The measurements were all performed at one site, the Cape Verde atmospheric observatory (CVAO), which lies in the outflow of the Saharan desert. These measurements and the output of a regional transport model were compared for this site.

One focus was on the calculation of the size-resolved deposition velocity. Two different methods were applied to determine the atmospheric turbulence parameters, which then served as input parameters to calculate the deposition veloc- ity according to the parameterizations by Zhang et al. (2001). The two methods are the micrometeorological and the profile method, which used the measurements of wind speed with an ultra-sonic and two 2-D anemometers, respectively. Both methods differed in the lowest particle diameter range $(0.1-0.3 \mu \mathrm{m})$ and also at about $2 \mu \mathrm{m}$, while the profile method showed generally higher values compared to the micrometeorological method. This may be due to the fact that the logarithmic wind profile for neutral atmospheric stratification was used in the profile measurements assuming stationarity, horizontal homogeneity and neutral atmospheric layering. These assumptions may not hold for the whole time period. However, the profile measurements are an effective and robust alternative for long-term studies when micrometeorological measurements including sophisticated and timeconsuming data processing of ultra-sonic anemometers are not available. 
In addition to the deposition velocity, mass concentrations of mineral dust were determined to obtain the mass deposition flux of mineral dust. Differences occurred between mass concentrations of the microphysical method $M_{\mathrm{mp}}$ (particle mass size distribution of mineral dust) and of the optical method $M_{\mathrm{op}}$ (absorption spectroscopy), while the latter one often showed lower concentrations. Comparisons of $M_{\mathrm{mp}}$ and $M_{\mathrm{op}}$ with independently measured mass concentrations of mineral dust of the gravimetrical method $M_{\mathrm{gr}}$ using a Berner impactor showed agreement of $80 \%$ for $M_{\mathrm{mp}}$ and $M_{\mathrm{gr}}$ and $60 \%$ for $M_{\mathrm{op}}$ and $M_{\mathrm{gr}}$. Comparing the methods to each other, the optical and the gravimetrical method are easiest to handle. However, the optical method is inaccurate by determining the mass concentration of mineral dust due to assumption of the mass absorption coefficient. Using the Berner impactor needs time consuming evaluation and supervision of the low time resolved measurements. The most sophisticated method is the microphysical one with highly infrastructural effort and very sensible devices. However, the latter measurements can be performed online and autonomously. For the purpose of this paper it is the preferred method because it yields the most detailed information and highest data availability.

Values of deposition velocities and mass concentrations of mineral dust at the surface derived from the different methods were used to calculate the dry deposition fluxes of mineral dust at the CVAO. Scanning electron microscopy $\left(F_{\mathrm{SEM}}\right)$ was used to analyze the passive sampled mineral dust particles and calculate the mass and the deposition flux of mineral dust. In addition, the Saharan mineral dust transport and deposition towards the tropical northeast Atlantic Ocean was simulated with a regional mineral dust emission and transport model, which provides size-resolved deposition fluxes in time and space. The mean values for January 2009 for the different measurement techniques vary between 12 and $29 \mathrm{ng} \mathrm{m}^{-2} \mathrm{~s}^{-1}$. The value of the regional model is $47 \mathrm{ng} \mathrm{m}^{-2} \mathrm{~s}^{-1}$. The lowest deposition flux was often obtained by the $F_{\mathrm{SEM}}$, which should be regarded as a minimum estimate of the atmospheric mass deposition flux of mineral dust to the ocean. The modeled dry mass deposition flux of mineral dust was often higher than the values derived from the ground-based remote sensing, but a good agreement was generally found in the temporal evolution.

All measurement techniques to obtain the mass deposition flux of mineral dust showed similar values for the different dust events. These methods can be used to create a long-term time series of dust deposition fluxes in the Cape Verde region. For the current paper, the combination of the micrometeorological and the microphysical method are the preferred one due to availability of detailed information. However, this shall not be a recommendation for other measurements. Depending on the location, infrastructure and outer conditions, another combination may be more preferable to obtain a high data set on mass deposition fluxes of mineral dust. Such a data set is desirable for the validation of dust transport mod- els and satellite products used to quantify the dust transport and deposition to the Atlantic. One has to take care, that such validations are only reasonable, when the dust layer is spread homogeneously over the grid cell where the measurements take place.

Acknowledgements. We thank J. Matschullat from the TU Bergakademie of Freiberg for supplying us with the Sigma-2 passive samplers. We also acknowledge good cooperation and support from the German weather service "Deutscher Wetterdienst" (DWD). B. Heinold would like to acknowledge funding from ERC grant 257543 "Desert Storms". The University of York measurements are funded by the National Centre for Atmospheric Science (NCAS) through the Facility of Groundbased Measurements (FGAM). The SOPRAN project is supported by the Bundesministerium für Bildung und Forschung (BMBF) grant number 03F0611J.

Edited by: N. Mihalopoulos

\section{References}

Arimoto, R., Ray, B. J., Lewis, N. F., Tomza, U., and Duce, R. A.: Mass-particle size distributions of atmospheric dust and the dry deposition of dust to the remote ocean, J. Geophys. Res.-Atmos., 102, 15867-15874, 1997.

Baker, A. R. and Croot, P. L.: Atmospheric and marine controls on aerosol iron solubility in seawater, Marine Chem., 120, 4-13, 2010.

Baron, P. A. and Willeke, K.: Aerosol Measurement, 2nd Edition, J. Wiley and Sons, 170-178, 2001.

Berkowicz, R. and Prahm, L. P.: Evaluation of the profile method for estimation of surface fluxes of momentum and heat, Atmos. Environ., 16, 2809-2819, 1982.

Boyd, P. W., Watson, A. J., Law, C. S., Abraham, E. R., Trull, T., Murdoch, R., Bakker, D. C. E., Bowie, A. R., Buesseler, K. O., Chang, H., Charette, M., Croot, P., Downing, K., Frew, R., Gall, M., Hadfield, M., Hall, J., Harvey, M., Jameson, G., LaRoche, J., Liddicoat, M., Ling, R., Maldonado, M. T., McKay, R. M., Nodder, S., Pickmere, S., Pridmore, R., Rintoul, S., Safi, K., Sutton, P., Strzepek, R., Tanneberger, K., Turner, S., Waite, A., and Zeldis, J.: A mesoscale phytoplankton bloom in the polar Southern Ocean stimulated by iron fertilization, Nature, 407, 695-702, 2000.

Cakmur, R. V., Miller, R. L., Perlwitz, J., Geogdzhayev, I. V., Ginoux, P., Koch, D., Kohfeld, K. E., Tegen, I., and Zender, C. S.: Constraining the magnitude of the global dust cycle by minimizing the difference between a model and observations, J. Geophys. Res.-Atmos., 111, D06207, doi:10.1029/2005JD005791, 2006.

Carlson, T. N. and Prospero, J. M.: The large-scale movement of Saharan air outbreaks over the Northern Equatorial Atlantic, J. Appl. Meteorol., 11, 283-297, 1972.

Carpenter, L. J., Fleming, Z. L., Read, K. A., Lee, J. D., Moller, S. J., Hopkins, J. R., Purvis, R. M., Lewis, A. C., Müller, K., Heinold, B., Herrmann, H., Fomba, K. W., van Pinxteren, D., Müller, C., Tegen, I., Wiedensohler, A., Müller, T., Niedermeier, N., Achterberg, E. P., Patey, M. D., Kozlova, E. A., Heimann, M., Heard, D. E., Plane, J. M. C., Mahajan, A., Oetjen, H., Ingham, 
T., Stone, D., Whalley, L. K., Evans, M. J., Pilling, M. J., Leigh, R. J., Monks, P. S., Karunaharan, A., Vaughan, S., Arnold, S. R., Tschritter, J., Pohler, D., Friess, U., Holla, R., Mendes, L. M., Lopez, H., Faria, B., Manning, A. J., and Wallace, D. W. R.: Seasonal characteristics of tropical marine boundary layer air measured at the Cape Verde Atmospheric Observatory, J. Atmos. Chem., 67, 87-140, 2010.

Chiapello, I., Bergametti, G., Gomes, L., Chatenet, B., Dulac, F., Pimenta, J., and Suares, E. S.: An additional low layer transport of Sahelian and Saharan dust over the north-eastern tropical Atlantic, Geophys. Res. Lett., 22, 3191-3194, 1995.

DeCarlo, P. F., Slowik, J. G., Worsnop, D. R., Davidovits, P., and Jimenez, J. L.: Particle morphology and density characterization by combined mobility and aerodynamic diameter measurements. Part 1: Theory, Aerosol Sci. Technol., 38, 1185-1205, 2004.

Dee, D. P., Uppala, S. M., Simmons, A. J., Berrisford, P., Poli, P., Kobayashi, S., Andrae, U., Balmaseda, M. A., Balsamo, G., Bauer, P., Bechtold, P., Beljaars, A. C. M., van de Berg, L., Bidlot, J., Bormann, N., Delsol, C., Dragani, R., Fuentes, M., Geer, A. J., Haimberger, L., Healy, S. B., Hersbach, H., Holm, E. V., Isaksen, L., Kallberg, P., Kohler, M., Matricardi, M., McNally, A. P., Monge-Sanz, B. M., Morcrette, J. J., Park, B. K., Peubey, C., de Rosnay, P., Tavolato, C., Thepaut, J. N., and Vitart, F.: The ERA-Interim reanalysis: configuration and performance of the data assimilation system, Q. J. Roy. Meteorol. Soc., 137, 553597, 2011.

Dietze, V., Fricker, M., Goltzsche, M., and Schultz, E.: Air quality measurement in German health resorts - Part 1: Methodology and verification, Gefahrstoffe - Reinhaltung der Luft, Air Qual. Control, 66, 45-53, 2006.

Dubovik, O., Sinyuk, A., Lapyonok, T., Holben, B. N., Mishchenko, M., Yang, P., Eck, T. F., Volten, H., Munoz, O., Veihelmann, B., van der Zande, W. J., Leon, J. F., Sorokin, M., and Slutsker, I.: Application of spheroid models to account for aerosol particle nonsphericity in remote sensing of desert dust, J. Geophys. Res.Atmos., 111, D11204, doi:10.1029/2006JD007443, 2006.

Duce, R. A., Liss, P. S., Merrill, J. T., Altlas, E. L., Buat-Menard, P., Hicks, B. B., Miller, J. M., Prospero, J. M., Arimoto, R., Church, T. M., Ellis, W. G., Galloway, J. N., Hansen, L., Jickells, T. D., Knap, A. H., Reinhardt, K. H., Schneider, B., Soudine, A., Tokos, J. J., Tsunogai, S., Wollast, R., and Zhou, M.: The atmospheric input of trace species to the world ocean, Global Biogeochem. Cy., 5, 193-259, 1991.

Ebert, M., Dahmen, J., Hoffmann, P., and Ortner, H. M.: Examination of clean room aerosol particle composition by total reflection X-ray analysis and electron probe microanalysis, Spectrochim. Acta Part B - Atom. Spectrosc., 52, 967-975, 1997.

Engelstaedter, S., Tegen, I., and Washington, R.: North African dust emissions and transport, Earth-Sci. Rev., 79, 73-100, 2006.

Falkowski, P. G.: Evolution of the nitrogen cycle and its influence on the biological sequestration of $\mathrm{CO}_{2}$ in the ocean, Nature, 387 , 272-275, 1997.

Falkowski, P. G., Barber, R. T., and Smetacek, V.: Biogeochemical controls and feedbacks on ocean primary production, Science, 281, 200-206, 1998.

Foken, T.: Micrometeorology, Springer, Berlin-Heidelberg, Germany, 308 pp., 2008.
Fung, I. Y., Meyn, S. K., Tegen, I., Doney, S. C., John, J. G., and Bishop, J. K. B.: Iron supply and demand in the upper ocean, Global Biogeochem. Cy., 14, 281-295, 2000.

Ginoux, P., Chin, M., Tegen, I., Prospero, J. M., Holben, B., Dubovik, O., and Lin, S. J.: Sources and distributions of dust aerosols simulated with the GOCART model, J. Geophys. Res.Atmos., 106, 20255-20273, 2001.

Goossens, D. and Rajot, J. L.: Techniques to measure the dry aeolian deposition of dust in arid and semi-arid landscapes: a comparative study in West Niger, Earth Surf. Proc. Landf., 33, 178195, 2008.

Goudie, A. S., and Middleton, N. J.: Desert Dust in the Global System, Springer, Heidelberg, 87-100, 2006.

Heinold, B., Helmert, J., Hellmuth, O., Wolke, R., Ansmann, A., Marticorena, B., Laurent, B., and Tegen, I.: Regional modeling of Saharan dust events using LM-MUSCAT: model description and case studies, J. Geophys. Res.-Atmos., 112, D11204, doi:10.1029/2006JD007443, 2007.

Heinold, B., Tegen, I., Schepanski, K., Tesche, M., Esselborn, M., Freudenthaler, V., Gross, S., Kandler, K., Knippertz, P., Müller, D., Schladitz, A., Toledano, C., Weinzierl, B., Ansmann, A., Althausen, D., Müller, T., Petzold, A., and Wiedensohler, A.: Regional modelling of Saharan dust and biomass-burning smoke Part I: model description and evaluation, Tellus B - Chem. Phys. Meteorol., 63, 781-799, 2011.

Held, A., Nowak, A., Wiedensohler, A., and Klemm, O.: Field measurements and size-resolved model simulations of turbulent particle transport to a forest canopy, J. Aerosol Sci., 37, 786-798, 2006.

Helmert, J., Heinold, B., Tegen, I., Hellmuth, O., and Wendisch, M.: On the direct and semidirect effects of Saharan dust over Europe: A modeling study, J. Geophys. Res.-Atmos., 112, D11204, doi:10.1029/2006JD007444, 2007.

Hinds, W. C.: Aerosol Technology: Properties, Behavior, and Measurement of Airborne Particles, Wiley, New York, 48-51, 1999.

Huneeus, N., Schulz, M., Balkanski, Y., Griesfeller, J., Prospero, J., Kinne, S., Bauer, S., Boucher, O., Chin, M., Dentener, F., Diehl, T., Easter, R., Fillmore, D., Ghan, S., Ginoux, P., Grini, A., Horowitz, L., Koch, D., Krol, M. C., Landing, W., Liu, X., Mahowald, N., Miller, R., Morcrette, J.-J., Myhre, G., Penner, J., Perlwitz, J., Stier, P., Takemura, T., and Zender, C. S.: Global dust model intercomparison in AeroCom phase I, Atmos. Chem. Phys., 11, 7781-7816, doi:10.5194/acp-11-7781-2011, 2011.

Jickells, T. D., An, Z. S., Andersen, K. K., Baker, A. R., Bergametti, G., Brooks, N., Cao, J. J., Boyd, P. W., Duce, R. A., Hunter, K. A., Kawahata, H., Kubilay, N., laRoche, J., Liss, P. S., Mahowald, N., Prospero, J. M., Ridgwell, A. J., Tegen, I., and Torres, R.: Global iron connections between desert dust, ocean biogeochemistry, and climate, Science, 308, 67-71, 2005.

Kaaden, N., Massling, A., Schladitz, A., Müller, T., Kandler, K., Schütz, L., Weinzierl, B., Petzold, A., Tesche, M., Leinert, S., Deutscher, C., Ebert, M., Weinbruch, S., and Wiedensohler, A.: State of mixing, shape factor, number size distribution, and hygroscopic growth of the Saharan anthropogenic and mineral dust aerosol at Tinfou, Morocco, Tellus B - Chem. Phys. Meteorol., 61, 51-63, 2009.

Kandler, K., Schütz, L., Deutscher, C., Ebert, M., Hofmann, H., Jackel, S., Jaenicke, R., Knippertz, P., Lieke, K., Massling, A., Petzold, A., Schladitz, A., Weinzierl, B., Wiedensohler, A., Zorn, 
S., and Weinbruch, S.: Size distribution, mass concentration, chemical and mineralogical composition and derived optical parameters of the boundary layer aerosol at Tinfou, Morocco, during SAMUM 2006, Tellus B - Chem. Phys. Meteorol., 61, 3250, 2009.

Karl, D., Michaels, A., Bergman, B., Capone, D., Carpenter, E., Letelier, R., Lipschultz, F., Paerl, H., Sigman, D., and Stal, L.: Dinitrogen fixation in the world's oceans, Biogeochemistry, 57, 47-98, 2002.

Karyampudi, V. M. and Carlson, T. N.: Analysis and numerical simulations of the Saharan Air Layer and its effect on easterly wave disturbances, J. Atmos. Sci., 45, 3102-3136, 1988.

Kaufman, Y. J., Koren, I., Remer, L. A., Tanre, D., Ginoux, P., and Fan, S.: Dust transport and deposition observed from the Terra-Moderate Resolution Imaging Spectroradiometer (MODIS) spacecraft over the Atlantic ocean, J. Geophys. Res.Atmos., 110, D10S12, doi:10.1029/2003JD004436, 2005.

Kirchstetter, T. W., Novakov, T., and Hobbs, P. V.: Evidence that the spectral dependence of light absorption by aerosols is affected by organic carbon, J. Geophys. Res.-Atmos., 109, D21208, doi:10.1029/2004JD004999, 2004.

Knutson, E. O. and Whitby, K. T.: Aerosol classification by electric mobility: apparatus, theory and applications, J. Aerosol Sci., 6, 443-451, 1975.

Kumar, N., Lurmann, F. W., Wexler, A. S., Pandis, S., and Seinfeld, J. H.: Development and application of a three dimensional aerosol model. In: Presented at the A\&WMA Specialty Conference on Computing in Environmental Resource Management, Research Triangle Park, NC, 2-4 December 1996.

Laurent, B., Heinold, B., Tegen, I., Bouet, C., and Cautenet, G.: Surface wind accuracy for modeling mineral dust emissions: Comparing two regional models in a Bodele case study, Geophys. Res. Lett., 35, L09804, doi:10.1029/2008GL033654, 2008.

Laurent, B., Tegen, I., Heinold, B., Schepanski, K., Weinzierl, B., and Esselborn, M.: A model study of Saharan dust emissions and distributions during the SAMUM-1 campaign, J. Geophys. Res.Atmos., 115, D21210, doi:10.1029/2009JD012995, 2010.

Leinert, S. and Wiedensohler, A.: A DMA and APS based technique for measuring aerodynamic hygroscopic growth factors of micrometer-size aerosol particles, J. Aerosol Sci., 39, 393-402, 2008.

Luo, C., Mahowald, N. M., and del Corral, J.: Sensitivity study of meteorological parameters on mineral aerosol mobilization, transport, and distribution, J. Geophys. Res.-Atmos., 108, D4447, doi:10.1029/2003JD003483, 2003.

Mahowald, N. M., Baker, A. R., Bergametti, G., Brooks, N., Duce, R. A., Jickells, T. D., Kubilay, N., Prospero, J. M., and Tegen, I.: Atmospheric global dust cycle and iron inputs to the ocean, Global Biogeochem. Cy., 19, GB4025, doi:10.1029/2004GB002402, 2005.

Majewski, D., Liermann, D., Prohl, P., Ritter, B., Buchhold, M., Hanisch, T., Paul, G., Wergen, W., and Baumgardner, J.: The operational global icosahedral-hexagonal gridpoint model GME: Description and high-resolution tests, Mon. Weather Rev., 130, 319-338, 2002.

Martin, J. H. and Fitzwater, S. E.: Iron-deficiency limits phytoplankton growth in the northeast Pacific Subartic, Nature, 331, 341343,1988
McTainsh, G. H., Nickling, W. G., and Lynch, A. W.: Dust deposition and particle size in Mali, West Africa, Catena, 29, 307-322, 1997.

Moore, C. M., Mills, M. M., Achterberg, E. P., Geider, R. J., LaRoche, J., Lucas, M. I., McDonagh, E. L., Pan, X., Poulton, A. J., Rijkenberg, M. J. A., Suggett, D. J., Ussher, S. J., and Woodward, E. M. S.: Large-scale distribution of Atlantic nitrogen fixation controlled by iron availability, Nature Geosci., 2, 867-871, 2009.

Moulin, C., Lambert, C. E., Dulac, F., and Dayan, U.: Control of atmospheric export of dust from North Africa by the North Atlantic oscillation, Nature, 387, 691-694, 1997.

Müller, T., Schladitz, A., Kandler, K., and Wiedensohler, A.: Spectral particle absorption coefficients, single scattering albedos and imaginary parts of refractive indices from ground based in situ measurements at Cape Verde Island during SAMUM-2, Tellus B - Chem. Phys. Meteorol., 63, 573-588, 2011.

Müller, T., Schladitz, A., Massling, A., Kaaden, N., Kandler, K., and Wiedensohler, A.: Spectral absorption coefficients and imaginary parts of refractive indices of Saharan dust during SAMUM-1, Tellus B - Chem. Phys. Meteorol., 61, 79-95, 2009.

Müller, K., Lehmann, S., van Pinxteren, D., Gnauk, T., Niedermeier, N., Wiedensohler, A., and Herrmann, H.: Particle characterization at the Cape Verde atmospheric observatory during the 2007 RHaMBLe intensive, Atmos. Chem. Phys., 10, 2709-2721, doi:10.5194/acp-10-2709-2010, 2010.

Prospero, J. M. and Carlson, T. N.: Vertical and areal distribution of Saharan dust over western equatorial North-Atlantic Ocean, J. Geophys. Res., 77, 5255-5265, 1972.

Prospero, J. M., Barrett, K., Church, T., Dentener, F., Duce, R. A., Galloway, J. N., Levy, H., Moody, J., and Quinn, P.: Atmospheric deposition of nutrients to the North Atlantic Basin, Biogeochemistry, 35, 27-73, 1996.

Renner, E. and Wolke, R.: modelling the formation and atmospheric transport of secondary inorganic aerosols with special attention to regions with high ammonia emissions, Atmos. Environ., 44, 1904-1912, 2010.

Ruijgrok, W., Tieben, H., and Eisinga, P.: The dry deposition of particles to a forest canopy: A comparison of model and experimental results, Atmos. Environ., 31, 399-415, 1997.

Schepanski, K., Tegen, I., Laurent, B., Heinold, B., and Macke, A.: A new Saharan dust source activation frequency map derived from MSG-SEVIRI IR-channels, Geophys. Res. Lett., 34, L18803, doi:10.1029/2007GL030168, 2007.

Schepanski, K., Tegen, I., and Macke, A.: Saharan dust transport and deposition towards the tropical northern Atlantic, Atmos. Chem. Phys., 9, 1173-1189, doi:10.5194/acp-9-1173-2009, 2009a.

Schepanski, K., Tegen, I., Todd, M. C., Heinold, B., Bonisch, G., Laurent, B., and Macke, A.: Meteorological processes forcing Saharan dust emission inferred from MSG-SEVIRI observations of subdaily dust source activation and numerical models, J. Geophys. Res.-Atmos., 114, L18803, doi:10.1029/2007GL030168, 2009b.

Schepanski, K., Tegen, I., and Macke, A.: Comparison of satellite based observations of Saharan dust source areas, Remote Sens. Environ., 123, 90-97, 2012.

Schladitz, A., Müller, T., Kaaden, N., Massling, A., Kandler, K., Ebert, M., Weinbruch, S., Deutscher, C., and Wiedensohler, A.: 
In situ measurements of optical properties at Tinfou (Morocco) during the Saharan Mineral Dust Experiment SAMUM 2006, Tellus B - Chem. Phys. Meteorol., 61, 64-78, 2009.

Shi, Z. B., Woodhouse, M. T., Carslaw, K. S., Krom, M. D., Mann, G. W., Baker, A. R., Savov, I., Fones, G. R., Brooks, B., Drake, N., Jickells, T. D., and Benning, L. G.: Minor effect of physical size sorting on iron solubility of transported mineral dust, Atmos. Chem. Phys., 11, 8459-8469, doi:10.5194/acp-11-84592011, 2011.

Slinn, S. A. and Slinn, W. G. N.: Predictions for particle deposition on natural-waters, Atmos. Environ. 14, 1013-1016, 1980.

Steppeler, J., Doms, G., Schattler, U., Bitzer, H. W., Gassmann, A., Damrath, U. and Gregoric, G.: Meso-gamma scale forecasts using the nonhydrostatic model LM, Meteorology and Atmospheric Physics, 82(1-4), 75-96, 2003.

Stull, R. B.: An Introduction to Boundary Layer Meteorology, 6 ed., Kluwer Academic Publishers, Dordrecht/Boston/London, 596601, 1988.

Swap, R., Ulanski, S., Cobbett, M., and Garstang, M.: Temporal and spatial characteristics of Saharan dust outbreaks, J. Geophys. Res.-Atmos., 101, 4205-4220, 1996.

Taubenheim, J.: Statistische Auswertung geophysikalischer und meteorologischer Daten, Akademische Verlagsgesellschaft Geest \& Portig K.-G., Leipzig, 111-119, 1969.

Tegen, I., Harrison, S. P., Kohfeld, K., Prentice, I. C., Coe, M., and Heimann, M.: Impact of vegetation and preferential source areas on global dust aerosol: Results from a model study, J. Geophys. Res.-Atmos., 107, 2002.

Tuch, T. M., Haudek, A., Müller, T., Nowak, A., Wex, H. and Wiedensohler, A.: Design and performance of an automatic regenerating adsorption aerosol dryer for continuous operation at monitoring sites, Atmos. Meas. Tech., 2(2), 417-422, 2009.

Wesely, M. L., Cook, D. R., Hart, R. L., and Speer, R. E.: Measurements and parameterization of particulate sulfur dry deposition over grass, J. Geophys. Res.-Atmos., 90, 2131-2143, 1985.
Wiedensohler, A.: An approximation of the bipolar chargedistribution for particles in the sub-micron size range, J. Aerosol Sci., 19, 387-389, 1988.

Wiedensohler, A., Birmili, W., Nowak, A., Sonntag, A., Weinhold, K., Merkel, M., Wehner, B., Tuch, T., Pfeifer, S., Fiebig, M., Fjaraa, A. M., Asmi, E., Sellegri, K., Depuy, R., Venzac, H., Villani, P., Laj, P., Aalto, P., Ogren, J. A., Swietlicki, E., Williams, P., Roldin, P., Quincey, P., Huglin, C., Fierz-Schmidhauser, R., Gysel, M., Weingartner, E., Riccobono, F., Santos, S., Gruning, C., Faloon, K., Beddows, D., Harrison, R., Monahan, C., Jennings, S. G., O’Dowd, C. D., Marinoni, A., Horn, H. G., Keck, L., Jiang, J., Scheckman, J., McMurry, P. H., Deng, Z., Zhao, C. S., Moerman, M., Henzing, B., de Leeuw, G., Loschau, G. and Bastian, S.: Mobility particle size spectrometers: harmonization of technical standards and data structure to facilitate high quality long-term observations of atmospheric particle number size distributions, Atmos. Meas. Tech., 5, 657-685, doi:10.5194/amt5-657-2012, 2012.

Wolke, R., Hellmuth, O., Knoth, O., Schröder, W., Heinrich, B., and Renner, E.: The chemistry-transport modeling system LMMUSCAT: Description and CityDelta applications, in Air Pollution modeling and Its Applications XVI, edited by: Borrego, C. and Incecik, S., Kluver Academic/Plenum Publishers, New York, 427-439, 2004.

Zender, C. S., Bian, H. S., and Newman, D.: Mineral Dust Entrainment and Deposition (DEAD) model: Description and 1990s dust climatology, J. Geophys. Res.-Atmos., 108, 4416, doi:10.1029/2002JD002775, 2003.

Zhang, L. M., Gong, S. L., Padro, J. and Barrie, L.: A sizesegregated particle dry deposition scheme for an atmospheric aerosol module, Atmos. Environ., 35, 549-560, 2001. 